Climent, M.J., Herrero-Hernández, E., Sánchez-Martín, M.J., Rodríguez-Cruz, M.S., Pedreros, P., Urrutia, R. 2019. Residues of pesticides and some metabolites in dissolved and particulate phase in surface stream water of Cachapoal River basin, central Chile. Environmental Pollution 251, pp. 90-101

\title{
Residues of Pesticides and Some Metabolites in Dissolved and Particulate Phase in Surface Stream Water of Cachapoal River Basin, Central Chile
}

\footnotetext{
María José Climent ${ }^{1,2}$, Eliseo Herrero-Hernández ${ }^{3, *}$, María Jesús Sánchez-Martín ${ }^{3}$, María Sonia Rodríguez-Cruz ${ }^{3}$, Pablo Pedreros ${ }^{1,2}$, Roberto Urrutia ${ }^{1,2}$

${ }^{1}$ Faculty of EnvironmentalSciences\& EULA Center, Universidad de Concepción, Barrio Universitario $s / n, 4030000$ Concepción, Chile.

${ }^{2}$ Center forWaterResourcesforAgriculture and Mining (CRHIAM), Universidad de Concepción, Victoria 1295, 4030000 Concepción, Chile.

${ }^{3}$ Institute of Natural Resources and Agrobiology of Salamanca, IRNASA-CSIC, c/ Cordel de Merinas, 40-52, 37008 Salamanca, España.
}

\section{Corresponding Autor}

Eliseo Herrero-Hernández

e-mail address: elihh@usal.es

Telephonenumber: +34 923219606; Fax: +34 923219609

Permanentaddress: c/ Cordel de Merinas, 40-52, 37008 Salamanca, España. 
21 Capsule: The occurrence of pesticides in the dissolved and particulate phase of aqueous

\section{Abstract}

In the last twenty years, pesticide use in Chile has increased more than $160 \%$, generating a greater risk of water resources pollution. The objective of this study was to assess the presence of 22 pesticides and 12 degradation products in surface water samples from the Cachapoal River basin, Central Chile, an area characterized by intense agricultural activity. Pesticide concentrations in the dissolved phase (DP) and particulate phase (PP) in samples collected in the dry season and after precipitation events was assessed. The solid-phase extraction technique was used to preconcentrate the samples and GC/MS and LC/MS were used to detect pesticides. The results present spatio-temporal variations in the proportion and concentration of pesticides and their degradation products in both the DP and PP for each site and sampling period. The most ubiquitous compounds in the dissolved phase were atrazine, atrazine-2-hydroxy (HA), cyprodinil, pyrimethanil, and tebuconazole, while in the particulate phase HA, imidacloprid, diazinon and pyrimidinol were detected. The results presented in this study make up the first record of pesticides in the dissolved and particulate phases in surface water in Chile. They show that the problem of pesticide contamination undoubtedly affects the quality of bodies of water in agricultural areas in Chile and support the need for a proper assessment of the water quality of the Cachapoal River in the future.

Keywords: dissolved phase, particulate phase, pesticides residues, pollution, surface water samples in the main agricultural region of Chile was revealed. Water samples of Cachapoal River basin were evaluated in the dry season and after precipitation events. 


\section{Introduction}

26 Since the 1990s, Latin American countries have experienced a considerable increase in

27 food production as a result of pesticide use, with Chile and Colombia applying the most

28 substances per area of arable land, reaching 15.6 and $20.8 \mathrm{~kg} \mathrm{ha}^{-1}$ in 2014 , respectively

29 (FAO, 2017). Although the application of pesticides is necessary to protect crops and meet

30 current food demand, it has been shown that the excessive use of these substances harms

31 beneficial natural enemies and non-target organisms, causes surface water, groundwater,

32 soil and air pollution and has negative public health impacts (Armstrong et al., 2013; Gibbs

33 et al., 2009; Zheng et al., 2016).

34 When a pesticide is applied, less than $1 \%$ reaches the target organism and the remaining

35 fraction is distributed among the plant foliage, soil, atmosphere, biota and aquatic systems

36 and is detected in areas far from the application point (Kuhad et al., 2004; Zhang et al.,

37 2004). Precipitation plays a fundamental role in the input of pesticides to waterbodies,

38 which reach this medium in the dissolved or particulate phase through surface or sub-

39 surface runoff, leaching, drift and/or post-use container cleaning(Arias-Estevez et al., 2008;

40 Bereswill et al., 2013). Mobility and persistence in environmental compartments depend on

41 the physiochemical properties of the compound (water solubility, half-life, Kow, Koc, etc.),

42 formulation (granule, powder, solution, suspension, etc.), soil characteristics (texture,

43 permeability, $\mathrm{pH}$, organic matter content, microbial activity, moisture, slope, etc.),

44 meteorological conditions (wind, precipitation, temperature, humidity, sunlight, etc.) and

45 agricultural practices (Navarro et al., 2007; Pereira et al., 2016).

46 The presence of pesticide residues and their degradation products in water resources has

47 caused concern among authorities in different countries of America, Asia or Europe since 
48 they have been detected in the dissolved and particulate phases at concentrations above 49 those established by the laws of different countries (Bereswill et al., 2013; Cruzeiro et al., 50 2015). In light of this situation, programs to monitor pesticides in surface water have been 51 developed to minimize their environmental impact and protect the quality of water 52 resources (Katagi, 2013; Lerch et al., 2017). In the case of the European Union (EU), the 53 maximum allowable individual and total pesticide concentrations established for human 54 consumption are $0.1 \mu \mathrm{g} \mathrm{L}^{-1}$ and $0.5 \mu \mathrm{g} \mathrm{L}^{-1}$, respectively (EC, 1998 and 2006) the laws of 55 these countries are among the strictest in the world (Knauer, 2016). Meanwhile, the Chilean 56 drinking water standard (INN, 2005) (NCh409/1 Of2005), establishes a maximum 57 allowable individual concentration only for the pesticides DDT (DDT + DDE + DDD), 2,4$58 \mathrm{D}$, lindane, metoxychlor and pentachlorophenol, at concentrations up to one hundred times 59 greater than those allowed by the EU. In addition, a comparison of the Chilean Standard on

60

61

62

63

64 65 66 67 68 69 70 71 Water Quality for Different Uses(INN, 1978) (NCh1333/Of1978) and EU Environmental Quality Standards for Priority Substances (EC, 2013) reveals that in Chile pesticides are only mentioned when deemed necessary by the competent authority and that the presence of insecticides in irrigation water is not deemed to have harmful effects.

Unlike in other countries in Latin America(Etchegoyen et al., 2017; Ferreira et al., 2016), in Chile there are few studies related to pesticide pollution of waterbodies; that of Montory et al. (2017) is the most recent.This investigation assessed the presence of organochlorine compounds in surface water of the Nuble River basin (Chile Central) at total concentrations that vary between 0.12 and $26.28 \mathrm{ng} \mathrm{L}^{-1}$. Similarly,Giordano et al. (2011) found residues of diazinon, lindane, chlorpyrifos, cyhalothrin, cypermethrin and fenvalerate in the Itata River. Palma et al. (2004) detected simazine, hexazinone, 2,4-D, picloram and carbendazim in water of the Traiguén River; Cooman et al. (2005) reported the presence of atrazine 
72 residues in the Chillán River and Dutka et al. (1996) detected some pesticides (triazine, 73 atrazine, metolachlor and benomyl) at surface water and sediment in Temuco and Rapel

74 River basin. All of these were found at concentrations that exceed the maximum allowable 75 individual concentration established by the European Union $\left(0.1 \mu \mathrm{g} \mathrm{L}^{-1}\right)$, except in Dutka et 76 al. (1996) who detected lower pesticide concentrations. Thus, the presence of pesticides in 77 surface water of agricultural and forestry land shows that waterbodies in Chile are 78 susceptible to pollution by phytosanitary compounds, as is the case at other sites around the 79 world.

80 More than 450 active principals are currently applied in Chile to control agricultural pests, 81 with pesticide sales increasing more than $160 \%$ in the last 20 years (FAO, 2017). Sales are 82 concentrated in the central part of the country due to the intense forestry, farming and 83 livestock activity that takes place in the VI Region (Libertador Bernardo O’Higgins, Figure 84 1), with over 30,000 tons sold in 2012 (SAG, 2012). This situation is worrying, since an 85 increase in the application of these substances could lead to a greater risk of water 86 resources pollution, negative environmental impacts and harm to public health.

87 While there are many studies that account for the presence of pesticides in the dissolved 88 phase in fresh waterbodies, most of those related to the presence of pollutants in the 89 particulate matter phase are limited, placing greater emphasis on organochlorine 90 compounds (PCBs, OCPs, HCHs) and polycyclic aromatic hydrocarbons (PAHs) due to

91 their affinity with organic matter(Liu et al., 2016). Nonetheless, the diversity and range of 92 pesticides physiochemical properties used in agricultural activity mean that they associate 93 with soil particles and can be transported by runoff to surface waterbodies, allowing them 94 to be detected in this matrix (Oliver et al., 2012). 
95 Accordingly, the objective of this work was to evaluate the presence of residues of most

96 usually used pesticides (herbicides, insecticides and fungicides) and some of degradation

97 products in surface water of Cachapoal River (CR) basin (Central Chile).The pesticide

98 analysis was carried out for the dissolved (DP) and particulate phase (PP) in samples

99 collected at different points of the river basin and in time periods corresponding to spring

100 (without rain), autumn (with and without rain) and winter (with rain).

101

102

\section{Materials and methods}

103

\subsection{Chemicals}

104 Thirty-four compounds were selected for this study, 7 herbicides (atrazine, simazine,

105 fluometuron, diuron, propazine, terbuthylazineand acetochlor), 7 insecticides (acephate, 106 imidacloprid, methidathion, azinphosmethyl, diazinon, chlorpyrifosand methamidophos), 9

107 fungicides (flutriafol, metalaxyl, cyproconazole, azoxystrobin, myclobutanil, pyrimethanil, 108 kresoxim-methyl, tebuconazole, cyprodinil) and 11 degradation products of those pesticides 109 most usually applied (deisopropylhydroxyatrazine, DIHA; deethylhydroxyatrazine, 110 DEHA;pyrimidinol, deisopropylatrazine, DIA; deethylatrazine, DEA; atrazine-2-hydroxy, 111 HA; CGA 92370,terbuthylazine-2-hydroxy, HT; desethylterbuthylazine, DET; diazoxon, 112 chlorpyrifosoxon). Selection of target analytes was based on the information on sales of 113 Agricultural Use Pesticides published by the Servicio Agrícola y Ganadero (SAG, 2012) $114\left(\mathrm{~kg} \mathrm{~L}^{-1}\right.$ of active ingredients used each year at the national level) in Chile. The 115 physicochemical properties of the studied compounds are summarized in Table 1.

116 The standards for analytes targeted were provided by Dr. Ehrenstorfer (Augsburg, 117 Germany) and Sigma-Aldrich (Gillingham, UK), and had a purity of > 98\%. A stock 118 solution in methanol for each compound at a concentration 500 or $1000 \mu \mathrm{g} \mathrm{mL} \mathrm{L}^{-1}$ and an 
119 intermediate $10 \mu \mathrm{g} \mathrm{mL}^{-1}$ solution for all of the analytes were prepared.All solutions were 120 stored in the dark at $4^{\circ} \mathrm{C}$. The solvents acetone, acetonitrile and methanol were supplied by 121 Fisher Scientific (Loughborough, UK); all were of HPLC-grade purity. The ultrapure 122 (UHQ) water was obtained with a Milli-Q system (Millipore, Milford, MA, USA).

\section{$124 \quad 2.2$ Study area description}

125 The Cachapoal River basin $\left(34^{\circ} 13^{\prime} 00^{\prime \prime} \mathrm{S} ; 70^{\circ} 47^{\prime} 00^{\prime \prime} \mathrm{O}\right)$ is located in Central Chile (VI 126 Region - Libertador Bernardo O’Higgins).It has a total surface area of $6370 \mathrm{~km}^{2}$ (DGA, 127 2004), of this area, 38.9\% is used for agricultural purposes, $31.3 \%$ consists of scrubland 128 and prairie, $3.6 \%$ is used for forestry plantations and the remaining $26.2 \%$ is used for other 129 purposes (Figure 1).Its main urban center is the city of Rancagua(34 $10^{\prime} 14^{\prime \prime} \mathrm{S} ; 7^{\circ} 44^{\prime} 39^{\prime \prime} \mathrm{O}$ ) 130 which has a surface area of approximately $260 \mathrm{~km}^{2}$ and 233,389 inhabitants.Forestry, 131 agricultural and livestock activity has a prominent place in the regional economy, 132 contributing $\$ 1,085,000,000,000$ to the national economy in 2015 and accounting for $13320.7 \%$ of the overall national forestry, farming and livestock(CHILE, 2016).

134 The central valley of the basin presents young, permeable, alluvial soils that allow intense 135 agricultural activity, with the cultivation of cereals and larger fruit trees such as apples, 136 peaches, plums, cherries, nectarines, pears, oranges, walnuts, avocadoes, almonds, lemons, 137 apricots and olives, as well as table grapes, standing out(CENMA, 2010; CIREN, 2015). A 138 temperate Mediterranean climate is predominant, with a long dry season, and well-defined 139 winter, with minimum temperatures below zero degrees and maximums over $28^{\circ} \mathrm{C}$. In 140 general, the recorded precipitation values are greater during the winter, especially during 141 the months of June, July and August(DGA, 2004). 
142 The main body of water is Cachapoal River (CR), which has a length of approximately 170

$143 \mathrm{Km}$, a pluvio-nival hydrological regime and average monthly streamflows that reach

144 maximums of around $180 \mathrm{~m}^{3} \mathrm{~s}^{-1}$ in July and $120 \mathrm{~m}^{3} \mathrm{~s}^{-1}$ in December (DGA, 2004). Its main

145 tributaries are La Cadena Stream (T-1), the Claro River (T-2) and Zamorano Stream (T-3),

146 which drain total surface areas of $497 \mathrm{~km}^{2}, 368 \mathrm{~km}^{2}$ and $990 \mathrm{~km}^{2}$, respectively(DGA, 147 2017).

\subsection{Collection of surface water samples}

150 Twenty-five surface water samples were collected for the dissolved phase (DP) pesticide 151 analysis in the period between September 2015 and July 2016, which included dry periods 152 and precipitation events. The first sampling was carried out in spring 2015 (on September 8 153 and October 27), with samples collected at five points in the Cachapoal River (CR-1, CR-2, 154 CR-3, CR-5, CR-6) and two tributaries (T-1 and T-2) (Figure 1).These months were 155 selected as representative of spring and coincided with the beginning of pesticide 156 application in the basin. The applied pesticides in this area varied according to the crop type 157 and pest, and there is no detailed information on pesticide types used or application dates; 158 however, the fruit inventory of 2015(CIREN, 2015), reveals that the main crops near 159 Cachapoal River and its tributaries are table grapes, drupes (cherries, peaches, nectarines, 160 avocadoes, plums, walnuts and almonds), pears, apples, oranges, kiwis, lemons and 161 mandarins.

162 The second sampling was done between April and June 2016. The samples were taken in 163 early autumn in a pre-rainfall period (April 13) and in autumn after rainfall (April 14) at 164 points in the Cachapoal River (CR-4) and three tributaries (T-1, T-2, T-3), as well as in 165 winter (July 13, after rainfall) in three tributaries (T-1, T-2, T-3). The dates and sampled 
166 sites in each case, as well as the daily precipitation levels recorded during these periods in

167 both the upper and lower parts of the basin, are indicated in Table 2. All samples were

168 collected in amber glass bottles and transported to the laboratory in isothermal boxes with

169 ice at $4^{\circ} \mathrm{C}$ for their subsequent analysis in triplicate.In less than 48 hours, the samples were

170 vacuum-filtered using nitrocellulose filters with a pore size $0.45 \mu \mathrm{m}$, with the aqueous

171 phase stored at $-20^{\circ} \mathrm{C}$ until its preconcentration via solid-phase extraction (SPE).

172 Some samples collected in September 2015 (CR-2, CR-3, T-2, CR-5 and CR-6) and April

1732016 following rainfall (T-1, T-2 and CR-4) presented suspended solids. This particulate

174 matter was separated by centrifuging (3000 rpm for $5 \mathrm{~min})$ the corresponding water and/or

175 recovering the solids retained in the nitrocellulose filters once the samples were vacuum-

176 filtered. The obtained material (20-50 g) was lyophilized and stored in an appropriate

177 container and the extraction and analysis of the selected pesticide residues were 178 subsequently carried out.

\subsection{Analysis of pesticide residues in water samples and particulate matter}

181 In order to assess the concentration of pesticides in the aqueous phase, the samples were 182 preconcentrated using the multi-residue methodology proposed by Climent et al. (2018). 183 Briefly, using Oasis HLB cartridges, $500 \mathrm{~mL}$ of water was preconcentrated in triplicate 184 with a peristaltic pump at a constant flow of $7 \mathrm{~mL} \mathrm{~min}^{-1}$. Each cartridge was previously 185 conditioned with $5 \mathrm{~mL}$ of acetone, $5 \mathrm{~mL}$ of acetonitrile and $10 \mathrm{~mL}$ of UHQ water. After the 186 passage of the sampler the cartridges were vacuum-dried under an air stream (-20 $\mathrm{mm} \mathrm{Hg})$ 187 for 5 minutes. The elution was carried out with $4 \mathrm{~mL}$ of acetone and $4 \mathrm{~mL}$ of acetonitrile. 188 The solvent was evaporated to dryness under a nitrogen stream and the residue was 
$190 \mu \mathrm{L}$ methanol in the case of GC-MS.

191 For the particulate matter samples, the pesticide residues and their degradation products

192 were extracted from the samples in triplicate using the multi-residue method optimized and 193 described byPose-Juan et al. (2014). Briefly, $10 \mathrm{~mL}$ of methanol/acetone mixture (50:50)

194 was added to $5.0 \mathrm{~g}$ of sample, maintaining constant agitation for $24 \mathrm{~h}$., followed by 195 centrifugation for $15 \mathrm{~min}$ at $3000 \mathrm{rpm}$.An 8-mL volume of supernatant was removed and 196 evaporated to dryness under a nitrogen stream, and the residue was redissolved in $500 \mu \mathrm{L}$ 197 of methanol/water mixture (1:1) for its analysis by LC-MS.

198 The linearity parameters and limits of detection (LOD) and quantification (LOQ) were 199 determined with a calibration curve between 0.075 and $1.5 \mu \mathrm{g} \mathrm{L}^{-1}$ for the dissolved phase 200 and between 0.1 and $1.0 \mu \mathrm{g} \mathrm{kg}^{-1}$ for the particulate matter phase. The quantification of the 201 samples in the DP was carried out through external calibration using matrix-matched 202 standards to correct signal enhancement or suppression. The PP analysis was carried out 203 using the standard addition method due to the difficulty of obtaining particulate matter 204 uncontaminated by pesticides, adding concentrations between 0.1 and $1.0 \mu \mathrm{g} \mathrm{mL} \mathrm{L}^{-1}$ of the 205 selected pesticides and degradation products to $5.0 \mathrm{~g}$ of particulate matter obtained for each 206 of the sampling points.

207 In both phases, the LOD and LOQ were estimated as 3 and 10 times the signal/noise ratio 208 for each analyte, respectively. In Table 3 the quality control parameters used to determine 209 pesticides and degradation products in the dissolved and particulate phases using LC/MS 210 are summarized in Climent et al. (2018), the quality control parameters used to determine 211 pesticides and degradation products in the dissolved phase using GC/MS are presented. 


\subsection{Equipment and chromatographic conditions}

214 The identification and quantification of the analytes was carried out through liquid 215 chromatography (LC) using a Waters (Milford, MA, USA) module equipped with a model 216 e2695 multisolvent delivery and autosampler system coupled to a Micromass-ZQ single 217 quadrupole mass spectrometer detector with an ESI interface, and gas chromatography 218 using an Agilent 7890 gas chromatograph coupled to an Agilent 5975 MSD mass 219 spectrometer (Agilent Technologies, Wilmington, DE, USA), under conditions proposed 220 byHerrero-Hernandez et al. (2013) andCliment et al. (2018),respectively. Because 221 methamidophos, diazoxon, azinphos-methyl and chlorpyrifos oxon are included in this 222 study, it was necessary to adjust the temperature ramps in GC-MS and the elution gradient 223 in LC-MS in order to obtain good compound separation. Table S1 and Table S2 indicate 224 the optimized chromatographic conditions for the analytic determination of pesticides and 225 degradation products through LC-MS (in dissolved and particulate phases) and GC-MS (in 226 dissolved phase).

\subsection{Statistic analysis for data processing}

229 The possible relationship between the physiochemical properties (water solubility, log 230 Kow, Koc and half-life in soil) of detected compounds and their total concentration in DD 231 and PP was assessed using statistical approximations. All analyses were performed with 232 IBM SPSS (version 22; USA) statistical software. A p value <0.05 was considered 233 statistically significant and when $r>0.5$ there is a relationship between pesticide average 234 concentration and physicochemical property.

\section{Results and discussion}




\subsection{Pesticide residues in the dissolved phase}

\section{$238 \quad 3.1 .1$ Samples collected in 2015}

239 The results of the analysis of the water samples collected in the Cachapoal River and its 240 tributaries in September and October 2015 (Figure 2a) showed that simazine, atrazine, 241 DIHA, DET, HA, pyrimethanil, cyprodinil, tebuconazole and methamidophos were the 242 most ubiquitous compounds, as they were detected in over $70 \%$ of the samples taken in 243 both samplings, at average concentrations at the different sampling points that fluctuated 244 between <LOQ and $1.127 \mu \mathrm{g} \mathrm{L}^{-1}$ (Table S3).

245 The compounds fluometuron, propazine, cyproconazole, kresoxim-methyl and azinphos246 methyl and degradation products HT, DEHA and CGA 92370 were not detected in any 247 sample, while terbuthylazine, DIA, DEA, azoxystrobin, imidacloprid, chlorpyrifos, 248 metalaxyl, diazinon and pyrimidinol were detected at concentrations $\leq 0.1 \mu \mathrm{g} \mathrm{L}^{-1}$ in less 249 than $42 \%$ of the samples taken in September and October. The rest of the pesticides were 250 detected sporadically at concentrations $<0.05 \mu \mathrm{g} \mathrm{L}^{-1}$.

251 An exception was the concentrations found for diuron and diazinon reaching maximum

252 levels of $0.363 \mu \mathrm{g} \mathrm{L}^{-1}$ and $0.318 \mu \mathrm{g} \mathrm{L}^{-1}$ respectively. The concentrations found for acephate 253 ranged between $0.293 \mu \mathrm{g} \mathrm{L}^{-1}$ and $4.887 \mu \mathrm{g} \mathrm{L}^{-1}$ constituting the highest detected (Table S3).

254 This can be attributed to the fact that acephate is a widely used insecticide in industrial 255 crops, rapeseed, vegetables, forestry plantations, cereals, fruit trees and grapes in the 256 Cachapoal River basin. Although this compound is easily degraded to methamidophos 257 under aerobic and anaerobic conditions (Szeto et al., 1979), its easy sorption to soil 258 particles, elevated solubility and persistence in water would explain its presence in the 259 dissolved phase(Suzuki, 2000). 
The concentrations detected in this study are consistent with the acephate levels reported in surface water in the Imperial Valley in Monterey County, California, where the concentration fluctuated between 0.132 and $13.5 \mu \mathrm{g} \mathrm{L}^{-1}$ (DPR, 2012). Similarly,Ingelse et al. (2001)assessed the presence of this compound in water samples collected in irrigation ditches and canals in various locations in the Netherlands, with the maximum concentrations detected at $0.2 \mu \mathrm{g} \mathrm{\textrm {L } ^ { - 1 }}$.

The spatial variation of pesticides in the main watercourse of the Cachapoal River during spring was assessed considering the entirety of the samples collected in September and October, the concentrations in both periods and the number of pesticides detected (Figure 3). An upward trend in the number of compounds detected from the upper zone to the lower zone of the Cachapoal River was observed. Specifically, site CR-6 presented the greatest number of compounds (21-22 of 34) of all of the sampled sites, while at CR-1 no pesticides were detected.In CR-2 only 2-3 of the 34 analyzed compounds were detected, but with only a DIHA concentration > LOQ $\left(1.015 \mu \mathrm{g} \mathrm{L}^{-1}\right.$ in September and $0.411 \mu \mathrm{g} \mathrm{L}^{-1}$ in October). At CR-3 the same number of compounds as at T-1 was detected, but at lower concentrations. Starting at site T-2, there was an increase in the number of fungicides and triazine-derived degradation products at each sampling site, with the appearance of compounds that were not detected in the upper part of the river such as DEA, flutriafol, myclobutanil, azoxystrobin, metalaxyl and diazinon.These differences can be attributed to pesticide input from the Claro River and Zamorano Stream, which enter the main watercourse at site T-2. Finally, all of the sites sampled in spring (except CR-1) presented a total pesticide concentration over the limit for human consumption established by the European Union (0.5 $\left.\mu \mathrm{g} \mathrm{L}^{-1}\right)$. Site $\mathrm{T}-1$ (La Cadena Stream) presented the highest total concentrations, reaching a maximum of $6.751 \mu \mathrm{g} \mathrm{L}^{-1}$ in September and $4.967 \mu \mathrm{g} \mathrm{L}{ }^{-1}$ in October, which can 
284 be explained by the continuous discharge of residues from wastewater treatment plants and

285 agroindustry operations situated in the northern zone of the Cachapoal River basin(DGA, 286 2010).

287 The spatial variations found in this study can be compared with those found in the works of 288 Ccanccapa et al. (2016) and Pascual Aguilar et al. (2017) in various rivers in Spain. 289 Ccanccapa et al. (2016) observed that in the Turia and Júcar rivers the most polluted areas 290 were located at the river mouths (downstream), with a strong relationship between pesticide 291 concentrations and the hydrology of the rivers (the greater the streamflow, the greater the 292 number of pesticides detected, but at lower concentrations; and the lower the streamflow, 293 the greater the pesticide concentration).In addition,Pascual Aguilar et al. (2017)found that 294 as the percentage of irrigated areas around the Júcar, Cabriel and Magro rivers increased, so 295 did the number and concentration and pesticides in the rivers, varying according to the 296 irrigation and crop type near the sampling sites. Therefore, for future investigations it 297 would be interesting to assess the influence of soil type, irrigation techniques, crop type and 298 pesticide application date on the concentration of these substances in the Cachapoal River 299 and its tributaries.

$301 \quad 3.1 .2$ Samples collected in 2016

302 The results of the analysis of the water samples collected in the autumn-winter period in 3032016 (Figure 2b) show that the most ubiquitous compounds were HA, terbuthylazine, 304 atrazine, pyrimethanil, cyprodinil, tebuconazole, imidacloprid and diazinon, which were 305 detected in all of the analyzed samples. The average concentrations of these compounds at 306 the different sampling points varied between $<$ LOQ and $0.736 \mu \mathrm{g} \mathrm{L}^{-1}$ in autumn (without 
rain), between < LOQ and $2.898 \mu \mathrm{g} \mathrm{L}^{-1}$ in autumn (with rain) and between < LOQ and

$3080.869 \mu \mathrm{g} \mathrm{L}^{-1}$ in winter (with rain) (Table S4).

309 Fluometuron, propazine, cyproconazole, pyrimidinol, diazoxon, azinphos-methyl and CGA 31092370 were not detected in any sample, while chlorpyrifos, acetochlor, HT and kresoxim311 methyl were only detected in one sample and/or site, at low concentrations or <LOQ. DIA, 312 flutriafol, methidathion and metalaxyl were detected only in the rainy period (autumn 313 and/or winter), while DEHA was detected in autumn in the period without rain at 314 concentrations that fluctuated between <LOQ and $0.485 \mu \mathrm{g} \mathrm{L}^{-1}$.

315 Methamidophos and DET presented concentrations < LOQ at more than one site and/or 316 sampling period, while myclobutanil, azoxystrobin and DEA presented similar 317 concentrations in the three periods. Finally, diuron, simazine, DIHA and chlorpyrifos oxon 318 presented a greater concentration in winter with rain. The highest concentration of acephate 319 was detected in autumn without rain.

320 Assessment of the pollution level by site (Figure 4) showed that the total pesticide 321 concentration in the dissolved phase exceeded the maximum allowable limit for human 322 consumption established by the EU $\left(0.5 \mu \mathrm{g} \mathrm{L}^{-1}\right)$ at all sites. T-1 and T-3 reached the highest 323 levels in winter with rain.

324 Regarding the total pesticide level by period and sampling site, an increase in the total 325 pesticide concentration was observed when comparing the sampling results in autumn 326 without rain and winter with precipitation, which is associated mainly with the increase in 327 the total herbicide concentration at sites $\mathrm{T}-1, \mathrm{~T}-2$ and $\mathrm{T}-3$. It is worth mentioning that the 328 total pesticide concentration at $\mathrm{T}-1$ and $\mathrm{T}-2$ remained relatively constant in autumn with 329 and without rain, while at T-3, concentrations increased considerably from $0.573 \mu \mathrm{g} \mathrm{L}^{-1}$ to $3303.651 \mu \mathrm{g} \mathrm{L}^{-1}$ due to the increase in the total fungicide concentration. 
331 At CR-4, there was a decrease in the total pesticide concentration from $2.030 \mu \mathrm{g} \mathrm{L}^{-1}$ to

$3321.138 \mu \mathrm{g} \mathrm{L}^{-1}$ with the occurrence of autumn precipitation, since levels of both insecticides

333 and fungicides decreased to almost half of the initial concentration. In this case, the

334 concentration decrease could be explained by the effect caused by the contribution of the

335 Claro River upstream of CR-4, which could result in pesticide dilution in the main 336 watercourse.

337 The increase in pesticide concentration during or following a precipitation event has been 338 documented by various authors around the world, who have demonstrated that most of the 339 annual pollutant load in river systems is produced during flooding episodes(Eyre and Pont, 340 2003; Zonta et al., 2005). This explains the increase in the total concentration of pesticides 341 in dissolved phase at the sites sampled in the rainy season. For example, Ferreira et al. 342 (2016) reported significantly higher diuron levels during rainy periods in the Ipojuca River 343 sub-basin (Pernambuco, Brazil) compared to levels in the dry periods of the region. 344 Similarly, Dores et al. (2008) observed an increase in herbicide percentages detected in 345 surface waterbodies during the rainy seasons in the Primavera do Leste region, Mato 346 Grosso (Central-western Brazil), with atrazine, simazine and DEA the compounds detected 347 at the highest concentrations.In addition,Gregoire et al. (2010) assessed the concentration of 348 seventeen pesticides during rainfall-runoff events in the Hohrain basin (Haut-Rhin, Alsace, 349 France), detecting diuron in more than $90 \%$ of the analyzed samples over four years, with 350 an average concentration of $3.7 \mu \mathrm{g} \mathrm{L}^{-1}$ in 2006 , as well as simazine and terbuthylazine at 351 average concentrations of $0.2 \mu \mathrm{g} \mathrm{L}^{-1}$ and $0.44 \mu \mathrm{g} \mathrm{L}^{-1}$ in 2003 , respectively.

352 Researchers in the United States (Battaglin et al., 2011; Orlando et al., 2013; Reilly et al., 353 2012) and Europe (Gonçalves et al., 2007; Herrero-Hernández et al., 2016; Rabiet et al., 354 2010; Wightwick et al., 2010) have reported fungicide residues such as azoxystrobin, 
metalaxyl, myclobutanil, pyrimethanil and tebuconazole in surface waterbodies near vegetable-growing areas, with the aforementioned compounds detected most frequently and at the highest concentrations.

\subsection{Pesticide residues in the particulate phase}

The results of the particulate matter analysis indicate the presence of the residues HA, imidacloprid, diazinon and pyrimidinol in all of the samples collected in September 2015. In autumn 2016 (with rain) the most ubiquitous compounds were diuron, acetochlor, DEHA, DET, HA, pyrimethanil, cyprodinil, tebuconazole, metalaxyl, imidacloprid, diazinon and pyrimidinol, which were also detected at all of the sampled sites.

In general, pesticides concentration in PP fluctuated between $<$ LOQ and $1195 \mu \mathrm{g} \mathrm{kg}^{-1}$ for the samples collected in September 2015 and between < LOQ and $473.8 \mu \mathrm{g} \mathrm{kg}^{-1}$ for those collected in autumn 2016 (with rain) (Table S5).

Regarding the spatial distribution of each pesticide group (Figure 5 and Figure 6), it was observed that the percentage of triazine-derived degradation products was greater than that of insecticides, fungicides and herbicides at all the sampling sites, with DIHA and HA the compounds detected at the greatest concentrations. Site CR-3 presented the greatest total concentration $\left(2375 \mathrm{\mu g} \mathrm{kg}^{-1}\right)$ and number of pesticides (11 of 33) in the September 2015 sampling (Figure 5), while in the autumn (with rain) sampling, T-1 presented the highest total concentration (1199 $\mu \mathrm{g} \mathrm{kg}$ ), although the lowest number of compounds were detected (14 of 33) (Figure 6).

Regarding compound type, CR-3 and T-2 presented the greatest insecticide percentages in 2015, with maximum levels of $259.8 \mu \mathrm{g} \mathrm{kg}^{-1}$ and $357.8 \mu \mathrm{g} \mathrm{kg}^{-1}$, respectively, while in 2016 $\mathrm{T}-1$ was the only site that presented insecticide concentrations > LOQ $\left(76.44 \mu \mathrm{g} \mathrm{kg}^{-1}\right) . \mathrm{T}-2$ 
and CR-5 were the only sites for which herbicide concentrations > LOQ in 2015. The total fungicide concentration at both sites, T-2 and CR-5, was approximately $20 \mu \mathrm{g} \mathrm{kg}^{-1}$ in 2015 and reached a maximum of $125.5 \mu \mathrm{g} \mathrm{kg}^{-1}$ in the samples collected in 2016 at $\mathrm{T}-1$ (Figure 5, Figure 6 and Table S5).

While different sites were sampled in the two periods (with the exception of T-2), it was observed that the number of compounds detected in autumn after the rainy period in 2016 was greater than the number of compounds detected in spring (September 2015), although in general they were detected at lower concentrations.

The most frequently found compounds in the particulate phase were triazine herbicide degradation products. However, to date there are few studies that have assessed the presence of these triazine-derived degradation products in the particulate phase in aqueous samples. In general the published works report the concentration of pesticides in the particulate phase as the difference in concentrations between unfiltered and filtered aqueous samples, making it difficult to compare the results of this study with those in the literature. Despite this limitation, the results obtained for DEA (maximum $5.67 \mu \mathrm{g} \mathrm{kg}^{-1}$ ) could be compared with those in the Saint Lawrence River (Canada) reported byDarwano et al. (2014) who found this compound at average concentrations that did not exceed $9 \mu \mathrm{g} \mathrm{kg}^{-1}$ in the particulate phase.In contrast,Cruzeiro et al. (2016) reported levels above $300 \mu \mathrm{g} \mathrm{kg}^{-1}$ in the Tagus River estuary (Portugal), a difference that can be attributed to the organic matter content and microbial activity in the aqueous samples from each ecosystem.

It is worth mentioning that DIA was detected only in the dissolved phase (Azevedo et al., 2010; Gfrerer et al., 2002), and to date there are no known investigations that report the presence of this substance in the particulate phase. Finally, the presence of HA, DET, DEA, DEHA, DIHA and HT in the particulate phase in the Cachapoal River basin may be due to 
the frequent use of simazine, terbuthylazine and atrazine in the crops near the sampled

404 sites; these compounds were detected in the dissolved phases, as they were in other rivers in

405 South America, Asia, the United States and Europe.

406 Regarding concentration of fungicides in the particulate phase, the presence of 407 pyrimethanil, cyprodinil, tebuconazole and metalaxyl stand out; their presence could be due 408 to the fact that, with the exception of metalaxyl, these compounds present low water 409 solubility $\left(13 \mathrm{mg} \mathrm{L}^{-1}<\mathrm{Sw}<121 \mathrm{mg} \mathrm{L}^{-1}\right)$, high octanol-water partition coefficients $(2.84<$ $410 \log$ Kow < 4) and high organic carbon partition coefficients (429< Koc < 3111) (Table 1), 411 promoting their sorption to soil particles and input to waterbodies through runoff. It is 412 worth mentioning that these substances were also detected in the dissolved phase; therefore, 413 physiochemical properties are likely not the only factor that determines their presence in 414 the water samples.

415 Regarding the insecticides studied in this work, imidacloprid and diazinon and its 416 degradation product pyrimidinol were detected in all of the particulate matter samples, 417 while methamidophos, acephate and methidathion were found mainly in the dissolved 418 phase. These differences could be attributable to their wide range of water solubility (60 $\mathrm{mg}$ $419 \mathrm{~L}^{-1}<\mathrm{Sw}<790000 \mathrm{mg} \mathrm{L}^{-1}$ ), as well as their highly variable organic carbon and octanol420 water partition coefficients $\left(1 \mathrm{ml} \mathrm{g}^{-1}<\mathrm{Koc}<609 \mathrm{ml} \mathrm{g}^{-1} ;-0.85<\log \mathrm{Kow}<3.69\right)$, favoring 421 the presence of these compounds in both phases.

422 Some of the organophosphate insecticides assessed in this investigation have also been 423 studied in rivers of Europe, similar concentrations to those detected in this work were 424 reported. For example, in the study published byCruzeiro et al. (2016) observed that 425 diazinon was one of the pesticides detected with the greatest frequency in the Tagus River 426 estuary, with average concentrations of $0.106 \mu \mathrm{g} \mathrm{L}^{-1}$ in the dissolved phase and $2740 \mu \mathrm{g} \mathrm{kg}^{-}$ 
$427{ }^{1}$ in the particulate phase. Similarly, Montuori et al. (2016) estimated the discharge of 428 organophosphate pesticides from the Tiber River to the Tyrrhenian Sea in central Italy. In 429 their study, chlorpyrifos and diazinon were detected in both phases. The authors mainly 430 attributed their presence to agricultural practices, meteorological and hydrological events in 431 the study area.

432 It is important to stress that the Cachapoal River presents a mixed hydrological regime, 433 with pluvial input from Zamorano Stream and pluvio-nival input from the Claro River and 434 La Cadena Stream. During 2015 precipitation in the lower basin was concentrated in the 435 months of July and August, with maximums of $59.4 \mathrm{~mm}$ and $103.6 \mathrm{~mm}$, respectively, while 436 in the sampling period precipitation decreased to zero in September and October. In 2016 437 precipitation presented maximums of $58 \mathrm{~mm}$ in April and $111.8 \mathrm{~mm}$ in July, while during 438 the sampling dates it reached just $1.8 \mathrm{~mm}$ in early October, increasing to $16.8 \mathrm{~mm}$ in 439 autumn and reaching $33.4 \mathrm{~mm}$ in winter (DGA, 2017).Therefore, the variation in the 440 concentration and number of compounds detected in both phases in the Cachapoal River 441 could be due to the heterogeneity of precipitation and variation in streamflow and organic 442 matter input along the river during the sampling period.

443 It is also important to state that the soils of the recent terraces of the Cachapoal River are 444 stratified, thin to slightly deep, with medium to moderately coarse textures over a sand and 445 gravel substrate, permeable $-50 \%$ of the soils present good drainage, $30 \%$ moderate 446 drainage and $20 \%$ imperfect drainage - and affected by occasional flooding 447 problems(CIREN, 2010). Therefore, the variation in the agrology of the soils along the 448 watercourse would explain the higher or lower entry of pesticides into the Cachapoal 449 River(Kellogg et al., 2002) . 


\subsection{Statistical analysis}

452 A direct significant relationship was found between the pesticide average concentration for 453 samples collected in 2015 (DP) with water solubility $(\mathrm{r}=0.86, p<0.05)$ and $\log$ Kow $(\mathrm{r}=$ $4540.62, p<0.05)$ considering diuron, terbuthylazine, atrazine, DIHA, DIA, DEA, flutriafol, 455 pyrimethanil, tebuconazole, azoxystrobin, acephate, imidacloprid, diazinon, pyrimidinol, 456 chlorpyrifos and chlorpyrifos oxon. Although during the spring 2015 period precipitation 457 was recorded only in the upper part of the basin (Table 2), the stability of the 458 aforementioned compounds toward aqueous hydrolysis and possible application during the 459 sampling period, would explain their detection in the analyzed samples.

460 In the same way, a direct and significant relationship was observed between average 461 pesticide concentration and water solubility sampled in 2016 in DP. This is true for samples 462 collected in autumn without precipitation $(\mathrm{r}=0.64, p<0.05)$. In autumn with precipitation $463(\mathrm{r}=0.69, p<0.05$, with the exception of pyrimethanil $)$ and in winter with rain $(\mathrm{r}=0.81, p<$ 4640.05 , with the exception of diuron and simazine).It is worth mentioning that there was no 465 correlation between the pesticide averageconcentrations in DP for sampled collected in 4662016 and other physiochemical properties (half-life in soil and Koc), except between log 467 Kow and pesticide concentrations detected in winter with rain $(r=0.56, p<0.05)$.

468 Finally, for detected compounds in PP, a direct and significant correlation was found 469 between pesticide average concentration with Koc coefficient $(r=0.77, p<0.05$, except for 470 chlorpyrifos and cyprodinil) and half life in soil $(\mathrm{r}=0.69, p<0.05)$. Therefore, it can be

471 established that the concentrations of some pesticides in the dissolved phase are influenced 472 by their water solubility, especially in the autumn and winter period, since precipitation 473 favors the entry of pesticides into the main watercourse and its tributaries. On the other 
474 hand, the presence of pesticides in particulate phase would be associated with its affinity

475 for organic matter present in the soil particles that reach waterbodies by runoff.

477 Conclusions

478 More than one pesticide was detected at most of the studied sites in both the dissolved and

479 particulate phases at concentrations above the maximum total $\left(0.5 \mu \mathrm{g} \mathrm{L}^{-1}\right)$ and individual

480 allowable concentrations $\left(0.1 \mu \mathrm{g} \mathrm{L}^{-1}\right)$ for human consumption established by the EU.

481 Taking into account all of the sampled sites and periods, acephate and DIHA were the

482 compounds that presented the highest concentrations in the dissolved phase for samples

483 taken in 2015. In 2016, the highest concentrations were found for diuron and pyrimethanil.

484 In the case of particulate matter, for both periods, the concentration of triazine-derived 485 degradation products was the highest, with DIHA and HA detected at the highest

486 concentrations. In general, significant variations in total and individual concentrations of

487 pesticides in both phases were observed. This can be attributed to both the physiochemical

488 properties of pesticides, climatic and geographic conditions of the study area. Finally, of all

489 of the sampled sites, T-1 (La Cadena Stream) presented the highest total concentration of 490 pesticides in the dissolved phase for samples collected in spring, autumn (without rain) and

491 winter, as well as the highest concentration of particulate pesticides during the precipitation

492 event in autumn. This work is the first study in Chile to account for the presence of 493 pesticides and their degradation products in the dissolved and particulate phases in fresh 494 waterbodies, reflecting the vulnerability of rivers and streams to pesticide pollution in the 495 Cachapoal River basin. Thus, it proves necessary to carry out more detailed studies on the 496 subject in which spatio-temporal pollution of surface water is assessed, taking into account 497 crop type and seasonal pesticide application. Additionally, it is necessary to assess the 
498 possible pollution of groundwater adjacent to farmland, since in many cases it is used for 499 domestic purposes.

500

501 Acknowledgement

502 This work was partly funded by the Government of Spain (MINECO/FEDER UE) as part 503 of Project AGL2015-69485-R and project CRHIAM/CONICYT/FONDAP/15130015. 504 María José Climent thanks both the National Commission for Scientific and Technological 505 Research (CONICYT $\mathrm{N}^{\circ}$ 21150573) and Water Research Center for Agriculture and 506 Mining for the financing used to carry out this work. 


\section{REFERENCES}

Arias-Estevez, M., Lopez-Periago, E., Martinez-Carballo, E., Simal-Gandara, J., Mejuto, J.C., Garcia-Rio, L., 2008. The mobility and degradation of pesticides in soils and the pollution of groundwater resources. Agric. Ecosyst. Environ. 123, 247-260.

Armstrong, J.L., Fenske, R.A., Yost, M.G., Galvin, K., Tchong-French, M., Yu, J., 2013. Presence of organophosphorus pesticide oxygen analogs in air samples. Atmos. Environ. $66,145-150$.

Azevedo, D.A., Silva, T.R., Knoppers, B.A., Schulz-Bull, D., 2010. Triazines in the tropical lagoon system of Mundaú-Manguaba, NE-Brazil. Journal of the Brazilian Chemical Society 21, 1096-1105.

Battaglin, W.A., Sandstrom, M.W., Kuivila, K., Kolpin, D.W., Meyer, M.T., 2011. Occurrence of azoxystrobin, propiconazole, and selected other fungicides in US streams, 2005-2006. Water, Air, and Soil Pollution 218, 307-322.

Bereswill, R., Streloke, M., Schulz, R., 2013. Current-use pesticides in stream water and suspended particles following runoff: Exposure, effects, and mitigation requirements. Environ. Toxicol. Chem. 32, 1254-1263.

Ccanccapa, A., Masiá, A., Andreu, V., Picó, Y., 2016. Spatio-temporal patterns of pesticide residues in the Turia and Júcar Rivers (Spain). Sci. Total Environ. 540, 200-210.

CENMA, 2010. Análisis de la composición físico química de los sedimentos fluviales y su relación con la disponibilidad de metales en agua, cuenca del río Cachapoal.

CIREN, 2010. Estudio Agrológico Región de O’Higgins. Descripción de Suelos, Materiales y Símbolos., in: Centro de Información de Recursos Naturales, C.C. (Ed.). Centro de Información de Recursos Naturales, pp. 1-592.

CIREN, 2015. Catastro Frutícola. Principales Resultados, Región del Libertador General Bernardo O’Higgins, Julio 2015.

Climent, M.J., Sánchez-Martín, M.J., Rodríguez-Cruz, M.S., Pedreros, P., Urrutia, R., Herrero-Hernández, E., 2018. Determination of Pesticides in River Surface Waters of Central Chile using SPE-GC-MS Multi-Residue Method. Journal of the Chilean Chemical Society 63, 4023-4031.

Cooman, K., Debels, P., Gajardo, M., Urrutia, R., Barra, R., 2005. Use of Daphnia spp. for the ecotoxicological assessment of water quality in an agricultural watershed in southcentral Chile. Arch. Environ. Contam. Toxicol. 48, 191-200.

Cruzeiro, C., Pardal, M.Â., Rocha, E., Rocha, M.J., 2015. Occurrence and seasonal loads of pesticides in surface water and suspended particulate matter from a wetland of worldwide interest - the Ria Formosa Lagoon, Portugal. Environ. Monit. Assess. 187, 669. 
Cruzeiro, C., Pardal, M.A., Rodrigues-Oliveira, N., Castro, L.F.C., Rocha, E., Rocha, M.J., 2016. Multi-matrix quantification and risk assessment of pesticides in the longest river of the Iberian peninsula. Sci. Total Environ. 572, 263-272.

CHILE, B.C.D., 2016. Cuentas Nacionales de Chile, PIB Regional, 2016, in: Chile, B.C.d. (Ed.). Banco Central de Chile, Banco Central de Chile.

Darwano, H., Duy, S.V., Sauve, S., 2014. A New Protocol for the Analysis of Pharmaceuticals, Pesticides, and Hormones in Sediments and Suspended Particulate Matter From Rivers and Municipal Wastewaters. Arch. Environ. Contam. Toxicol. 66, 582-593.

DGA, 2004. Diagnóstico y Clasificación de los Cursos y Cuerpos de Agua según Objetivos de Calidad, Cuenca del rio Rapel., in: Direción General de Aguas, G.d.C. (Ed.), pp. 1-190.

DGA, 2017. Red de Estaciones Hidrometeorológicas de la Dirección General de Aguas. Chile.

Dores, E., Carbo, L., Ribeiro, M.L., De-Lamonica-Freire, E.M., 2008. Pesticide levels in ground and surface waters of Primavera do Leste region, Mato Grosso, Brazil. J. Chromatogr. Sci. 46, 585-590.

DPR, 2012. DPR study 252. Long-term monitoring, Central Coast and Imperial Valley, Year 2. . Department of Pesticide Regulation, State of California, USA., p. Surface Water Monitoring of Pesticides Database.

Dutka, B.J., McInnis, R., Jurkovic, A., Liu, D., Castillo, G., 1996. Water and sediment ecotoxicity studies in Temuco and Rapel River Basin, Chile. Environmental Toxicology and Water Quality 11, 237-247.

EC, 1998. Council Directive 98/83/EC of 3 November 1998 on the quality of water intended for human consumption. Official Journal of the European Union L330/32:5.12.98, $1-23$.

EC, 2006. Directive 2006/118/EC of the European Parliament and of the Council of 12 December 2006 on the protection of groundwater against pollution and deterioration. Official Journal of the European Union 2006; L 372/19-31.

Etchegoyen, M., Ronco, A., Almada, P., Abelando, M., Marino, D., 2017. Occurrence and fate of pesticides in the Argentine stretch of the Paraguay-Paraná basin. Environ. Monit. Assess. 189, 63.

Eyre, B.D., Pont, D., 2003. Intra- and inter-annual variability in the different forms of diffuse nitrogen and phosphorus delivered to seven sub-tropical east Australian estuaries. Estuarine, Coastal and Shelf Science 57, 137-148.

FAO, 2017. Pesticides use. Pesticides use, Chile., June 14, 2017 ed.

Ferreira, A.d.S.G., da Silva, H.C.M.P., Rodrigues, H.O.S., Silva, M., de Albuquerque Junior, E.C., 2016. Occurrence and spatial-temporal distribution of herbicide residues in the 
Ipojuca River sub-basin, Pernambuco, Brazil. Revista Brasileira De Engenharia Agricola E Ambiental 20, 1124-1128.

Gfrerer, M., Martens, D., Gawlik, B.M., Wenzl, T., Zhang, A., Quan, X., Sun, C., Chen, J., Platzer, B., Lankmayr, E., Kettrup, A., 2002. Triazines in the aquatic systems of the Eastern Chinese Rivers Liao-He and Yangtse. Chemosphere 47, 455-466.

Gibbs, K.E., Mackey, R.L., Currie, D.J., 2009. Human land use, agriculture, pesticides and losses of imperiled species. Divers. Distrib. 15, 242-253.

Giordano, A., Richter, P., Ahumada, I., 2011. Determination of pesticides in river water using rotating disk sorptive extraction and gas chromatography-mass spectrometry. Talanta $85,2425-2429$.

Gonçalves, C.M., Esteves da Silva, J.C.G., Alpendurada, M.F., 2007. Evaluation of the Pesticide Contamination of Groundwater Sampled over Two Years from a Vulnerable Zone in Portugal. J. Agric. Food Chem. 55, 6227-6235.

Gregoire, C., Payraudeau, S., Domange, N., 2010. Use and fate of 17 pesticides applied on a vineyard catchment. Int. J. Environ. Anal. Chem. 90, 406-420.

Herrero-Hernandez, E., Andrades, M.S., Alvarez-Martin, A., Pose-Juan, E., RodriguezCruz, M.S., Sanchez-Martin, M.J., 2013. Occurrence of pesticides and some of their degradation products in waters in a Spanish wine region. J. Hydrol. 486, 234-245.

Herrero-Hernández, E., Pose-Juan, E., Sánchez-Martín, M.J., Andrades, M.S., RodríguezCruz, M.S., 2016. Intra-annual trends of fungicide residues in waters from vineyard areas in La Rioja region of northern Spain. Environ. Sci. Pollut. Res. 23, 22924-22936.

Ingelse, B.A., van Dam, R.C.J., Vreeken, R.J., Mol, H.G.J., Steijger, O.M., 2001. Determination of polar organophosphorus pesticides in aqueous samples by direct injection using liquid chromatography-tandem mass spectrometry. J. Chromatogr. A 918, 67-78.

INN, 1978. NORMA CHILENA OFICIAL NCh1333/Of1978. Requisitos de Calidad del Agua para Diferentes Usos, in: Chile, I.N.d.N.D.d.N. (Ed.).

INN, 2005. NORMA CHILENA OFICIAL NCh409/1.Of2005. Agua potable - Parte 1 Requisitos, in: Chile, I.N.d.N.D.d.N. (Ed.).

Katagi, T., 2013. Soil Column Leaching of Pesticides, in: Whitacre, D.M. (Ed.), Reviews of Environmental Contamination and Toxicology Volume 221. Springer New York, New York, NY, pp. 1-105.

Kellogg, R.L., Nehring, R.F., Grube, A., Goss, D.W., Plotkin, S., 2002. Environmental Indicators of Pesticide Leaching and Runoff from Farm Fields, in: Ball, V.E., Norton, G.W. (Eds.), Agricultural Productivity: Measurement and Sources of Growth. Springer US, Boston, MA, pp. 213-256. 
Knauer, K., 2016. Pesticides in surface waters: a comparison with regulatory acceptable concentrations (RACs) determined in the authorization process and consideration for regulation. Environmental Sciences Europe 28, 13.

Kuhad, R.C., Johri, A.K., Singh, A., Ward, O.P., 2004. Bioremediation of PesticideContaminated Soils, in: Singh, A., Ward, O.P. (Eds.), Applied Bioremediation and Phytoremediation. Springer Berlin Heidelberg, Berlin, Heidelberg, pp. 35-54.

Lerch, R.N., Lin, C.H., Goyne, K.W., Kremer, R.J., Anderson, S.H., 2017. Vegetative Buffer Strips for Reducing Herbicide Transport in Runoff: Effects of Buffer Width, Vegetation, and Season. J. Am. Water Resour. Assoc. 53, 667-683.

Liu, J., Qi, S.H., Yao, J., Yang, D., Xing, X.L., Liu, H.X., Qu, C.K., 2016. Contamination characteristics of organochlorine pesticides in multimatrix sampling of the Hanjiang River Basin, southeast China. Chemosphere 163, 35-43.

Montory, M., Ferrer, J., Rivera, D., Villouta, M.V., Grimalt, J.O., 2017. First report on organochlorine pesticides in water in a highly productive agro-industrial basin of the Central Valley, Chile. Chemosphere 174, 148-156.

Montuori, P., Aurino, S., Garzonio, F., Sarnacchiaro, P., Polichetti, S., Nardone, A., Triassi, M., 2016. Estimates of Tiber River organophosphate pesticide loads to the Tyrrhenian Sea and ecological risk. Sci. Total Environ. 559, 218-231.

Navarro, S., Vela, N., Navarro, G., 2007. Review. An overview on the environmental behaviour of pesticide residues in soils. Span. J. Agric. Res. 5, 357-375.

Oliver, D.P., Kookana, R.S., Anderson, J.S., Cox, J.W., Waller, N., Smith, L.H., 2012. Offsite transport of pesticides in dissolved and particulate forms from two land uses in the Mt. Lofty Ranges, South Australia. Agric. Water Manage. 106, 78-85.

Orlando, J., Smalling, K., Reilly, T., Boehlke, A., Meyer, M., M Kuivila, K., 2013. Occurrence of Fungicides and Other Pesticides in Surface Water, Groundwater, and Sediment from Three Targeted-Use Areas in the United States, 2009.

Palma, G., Sanchez, A., Olave, Y., Encina, F., Palma, R., Barra, R., 2004. Pesticide levels in surface waters in an agricultural-forestry basin in Southern Chile. Chemosphere 57, 763770.

Pascual Aguilar, J.A., Andreu, V., Campo, J., Picó, Y., Masiá, A., 2017. Pesticide occurrence in the waters of Júcar River, Spain from different farming landscapes. Sci. Total Environ. 607-608, 752-760.

Pereira, V.J., da Cunha, J., de Morais, T.P., Ribeiro-Oliveira, J.P., de Morais, J.B., 2016. Physical-chemical properties of pesticides: concepts, applications, and interactions with the environment. Biosci. J. 32, 627-641. 
648
Pose-Juan, E., Herrero-Hernández, E., Álvarez-Martín, A., Sánchez-Martín, M.J., Rodríguez-Cruz, M.S., 2014. Development of a procedure for the multiresidue analysis of pesticides in vineyard soils and its application to real samples. J. Sep. Sci. 37, 2215-2224.

Rabiet, M., Margoum, C., Gouy, V., Carluer, N., Coquery, M., 2010. Assessing pesticide concentrations and fluxes in the stream of a small vineyard catchment - Effect of sampling frequency. Environ. Pollut. 158, 737-748.

Reilly, T.J., Smalling, K.L., Orlando, J.L., Kuivila, K.M., 2012. Occurrence of boscalid and other selected fungicides in surface water and groundwater in three targeted use areas in the United States. Chemosphere 89, 228-234.

SAG, 2012. Informe de Venta de Plaguicidas de Uso Agrícola en Chile, in: Servicio Agrícola y Ganadero, D.P.A.y.F., Subdepartamento de Viñas y Vinos, Inocuidad y Biotecnología, Sección Inocuidad. (Ed.). Servicio Agrícola y Ganadero, pp. 1-113.

Suzuki, S., 2000. Leaching of several pesticides in andosol upland field under natural rain conditions. Journal of Pesticide Science 25, 1-9.

Szeto, S.Y., MacCarthy, H.R., Oloffs, P.C., Shepherd, R.F., 1979. The fate of acephate and carbaryl in water. Journal of Environmental Science and Health, Part B 14, 635-654.

Wightwick, A., Walters, R., Graeme Allinson, S.R.a.N.M.E.R.o.F.U.i.H.P.S., Fungicides, (Ed.), InTech, DOI: . Available from: , 2010. Environmental Risks of Fungicides Used in Horticultural Production Systems, in: Carisse, O. (Ed.).

Zhang, J., Lan, W., Qiao, C., Jiang, H., 2004. Bioremediation of Organophosphorus Pesticides by Surface-Expressed Carboxylesterase from Mosquito on Escherichia coli. Biotechnology Progress 20, 1567-1571.

Zheng, S., Chen, B., Qiu, X., Chen, M., Ma, Z., Yu, X., 2016. Distribution and risk assessment of 82 pesticides in Jiulong River and estuary in South China. Chemosphere 144, 1177-1192.

Zonta, R., Collavini, F., Zaggia, L., Zuliani, A., 2005. The effect of floods on the transport of suspended sediments and contaminants: A case study from the estuary of the Dese River (Venice Lagoon, Italy). Environ. Int. 31, 948-958. 
679 Figure 1. Land use map of Cachapoal River basin and sampling points (VI Región del 680 Libertador Bernardo O’Higgins, Central Chile). Self-elaboration based on data of Fruit 681 Catastro year 2015.

682 Figure 2. Individual concentrations $\left(\mu \mathrm{g} \mathrm{L}^{-1}\right)$ of pesticides and degradation products in 683 dissolved phase of surface water samples collected along Cachapoal River and its 684 tributaries in a) September and October (spring), year 2015 and b) April before prerain 685 (autumn), April after rainfall (autumn) and July after rainfall (winter) period, year 2016.

686 Figure 3. Total concentration of pesticides and degradation products $\left(\mu \mathrm{g} \mathrm{L}^{-1}\right)$, number of 687 detected compounds and spatial distribution of different pesticide groups (\%) in dissolved 688 phase of water samples collected along Cachapoal River and its tributaries. Data 689 correspond to average values determined in different sites in September-October period, 690 year 2015.

691 Figure 4. Total concentration of pesticides and degradation products $\left(\mu \mathrm{g} \mathrm{L}^{-1}\right)$, number of 692 detected compounds and spatial distribution of different pesticide groups (\%) in dissolved 693 phase of water samples collected along Cachapoal River and its tributaries. Data 694 correspond to values determined in different sites at each period (autumn before prerain, 695 autumn after rainfall and winter after rainfall), year 2016.

696 Figure 5. Total concentration of pesticides and degradation products $\left(\mu \mathrm{g} \mathrm{kg}^{-1}\right)$, number of 697 detected compounds and spatial distribution of different pesticide groups (\%) in particulate 698 phase of water samples collected along Cachapoal River and its tributaries. Data 699 correspond to values determined in different sites in September, year 2015.

700 Figure 6. Total concentration of pesticides and degradation products $\left(\mu \mathrm{g} \mathrm{kg}^{-1}\right)$, number of 701 detected compounds and spatial distribution of different pesticide groups (\%) in particulate 
702 phase of water samples collected along Cachapoal River and its tributaries. Data 703 correspond to values determined in different sites in April after rainfall, year 2016. 


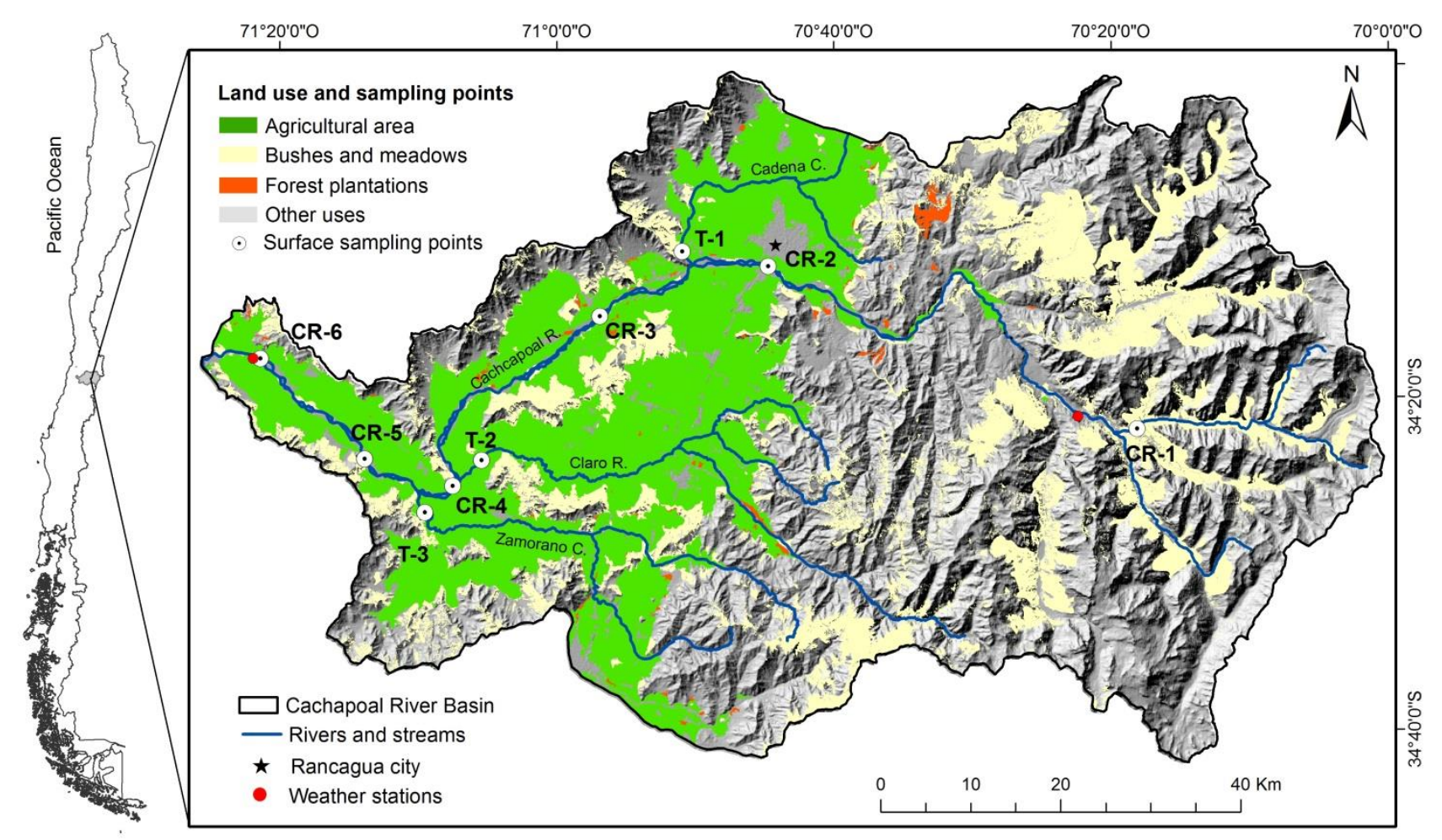

Figure 1. Land use map of Cachapoal River basin and sampling points (VI Región del Libertador Bernardo O’Higgins, Central Chile). Self-elaboration based on data of Fruit Catastro year 2015. 


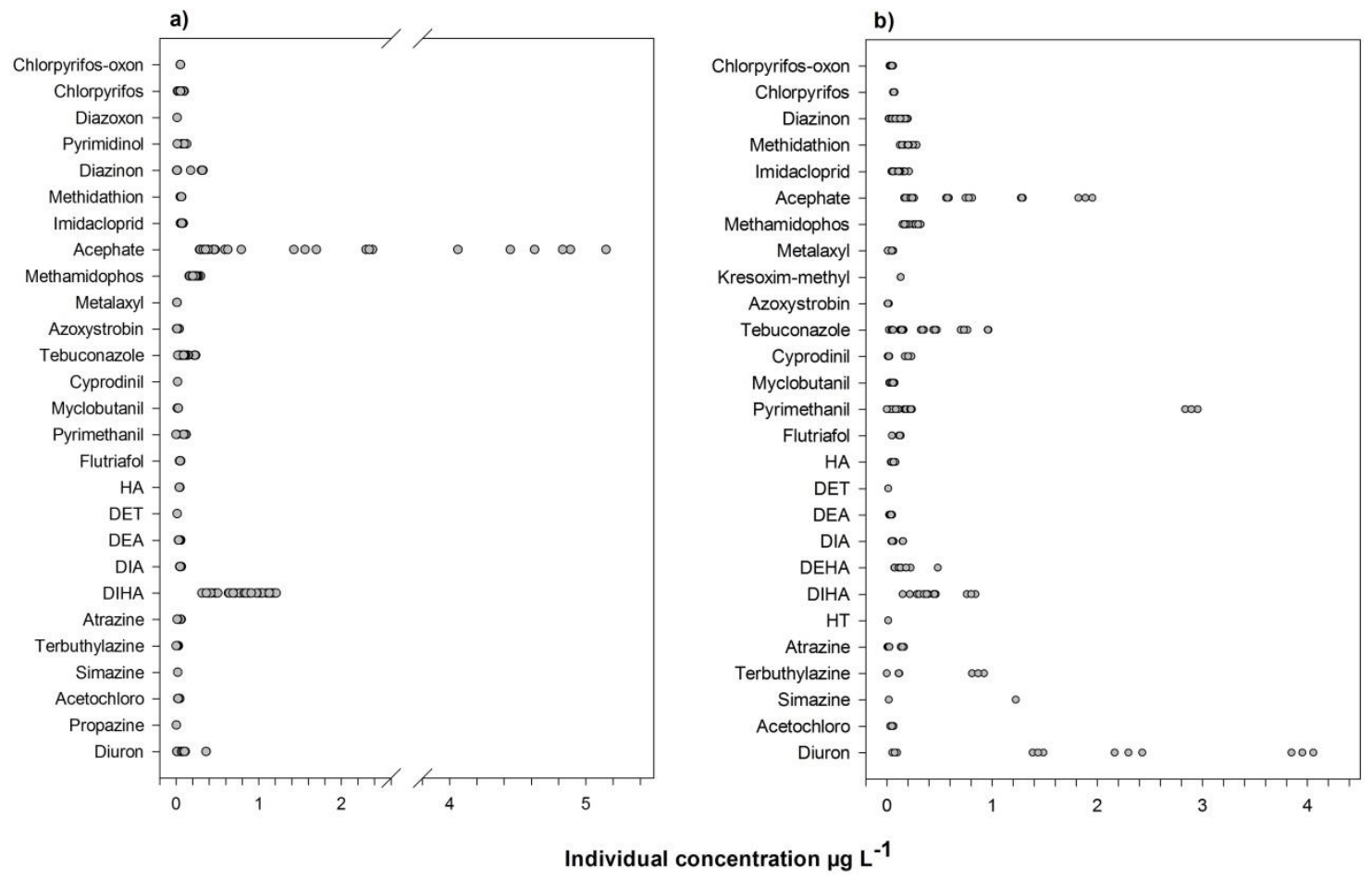

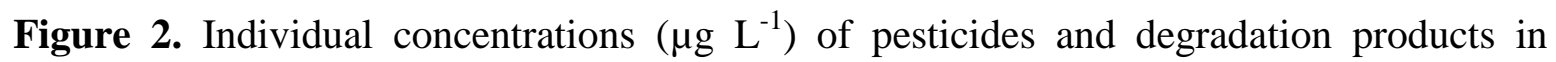
dissolved phase of surface water samples collected along Cachapoal River and its tributaries in a) September and October (spring), year 2015 and b) April before prerain (autumn), April after rainfall (autumn) and July after rainfall (winter) period, year 2016. 


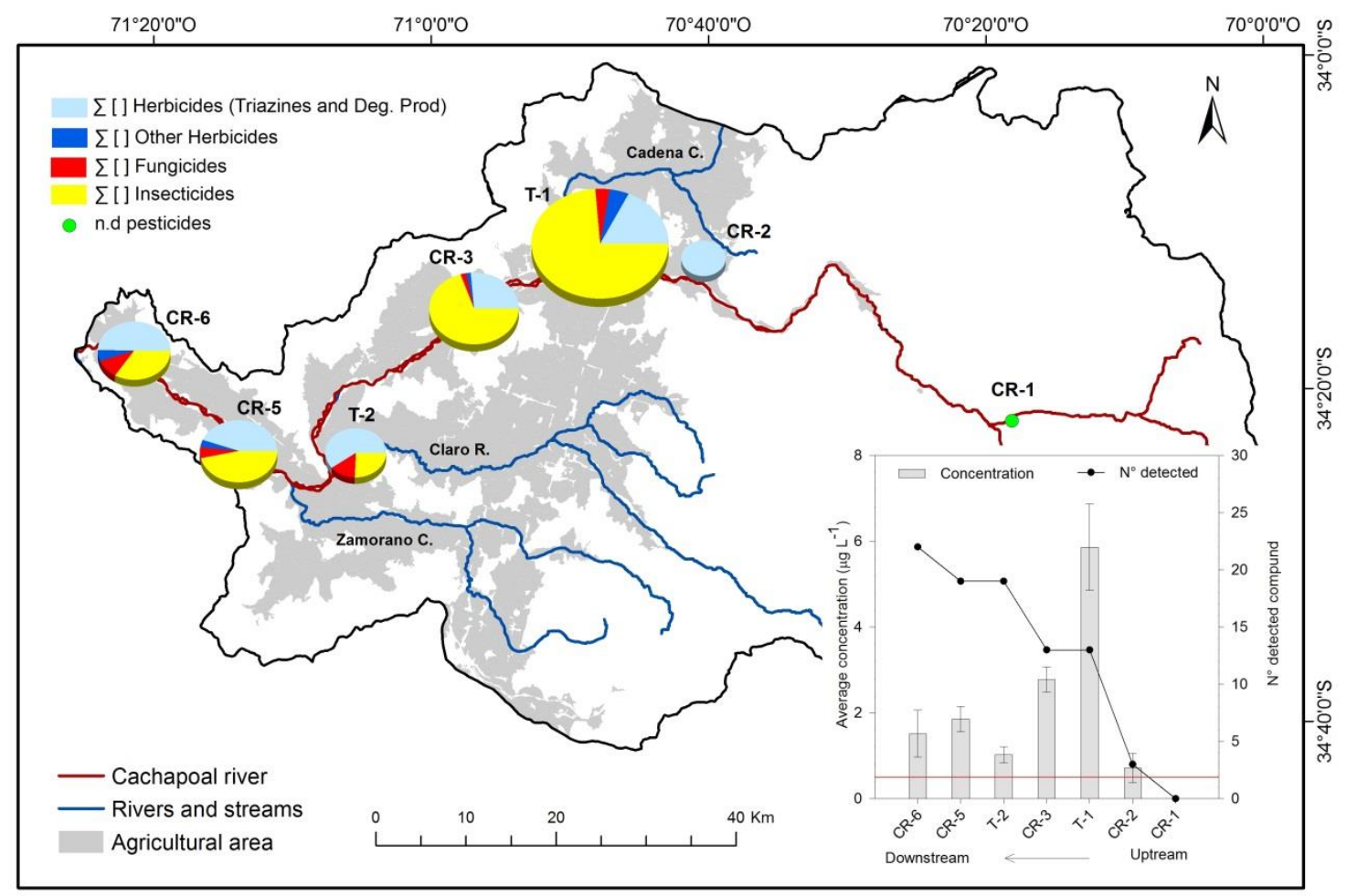

Figure 3. Total concentration of pesticides and degradation products $\left(\mu \mathrm{g} \mathrm{L}^{-1}\right)$, number of detected compounds and spatial distribution of different pesticide groups (\%) in dissolved phase of water samples collected along Cachapoal River and its tributaries. Data correspond to average values determined in different sites in September-October period, year 2015 . 


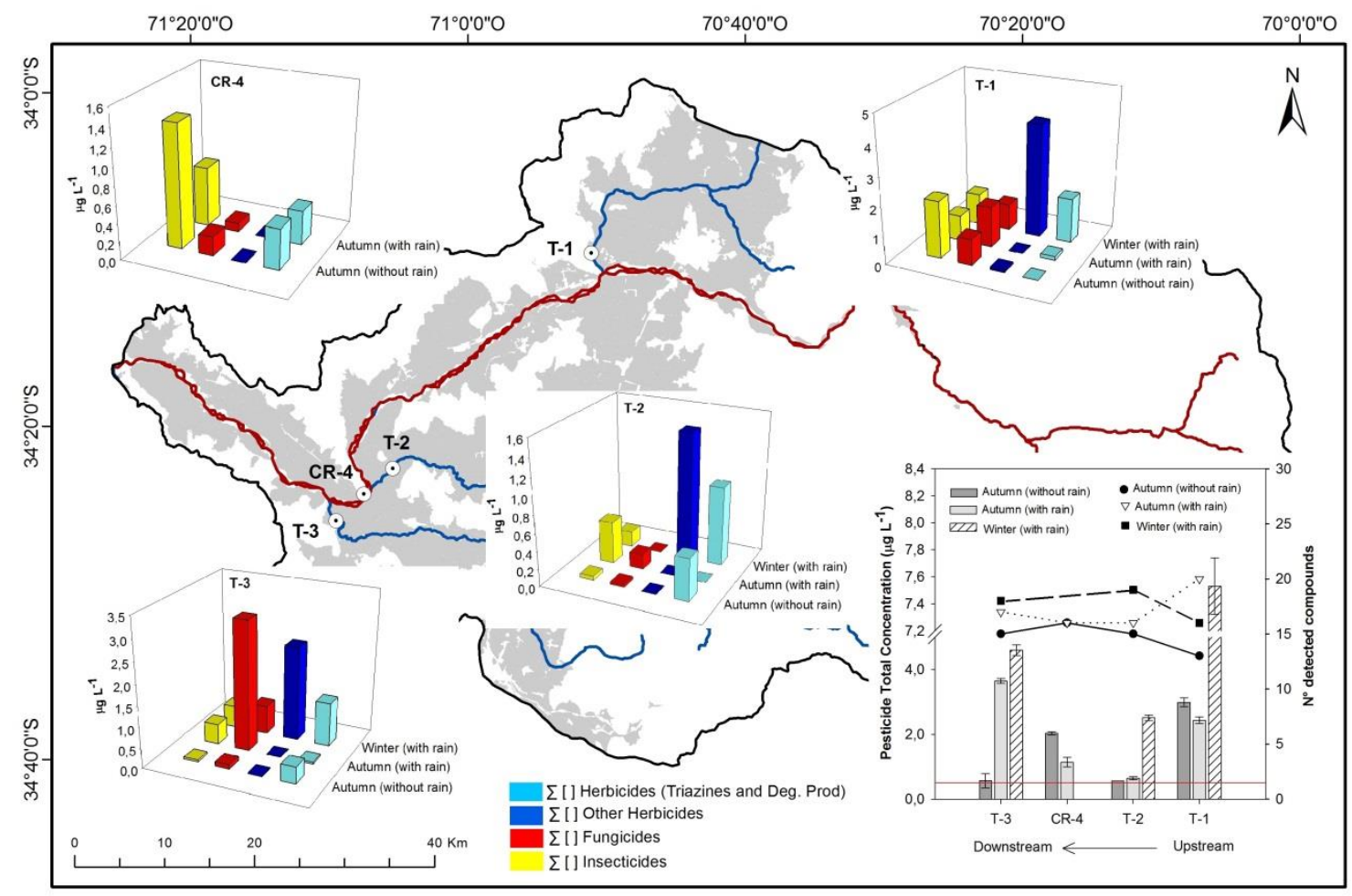

Figure 4. Total concentration of pesticides and degradation products ( $\mu \mathrm{g} \mathrm{L}^{-1}$ ), number of detected compounds and spatial distribution of different pesticide groups (\%) in dissolved phase of water samples collected along Cachapoal River and its tributaries. Data correspond to values determined in different sites at each period (autumn before prerain, autumn after rainfall and winter after rainfall), year 2016. 


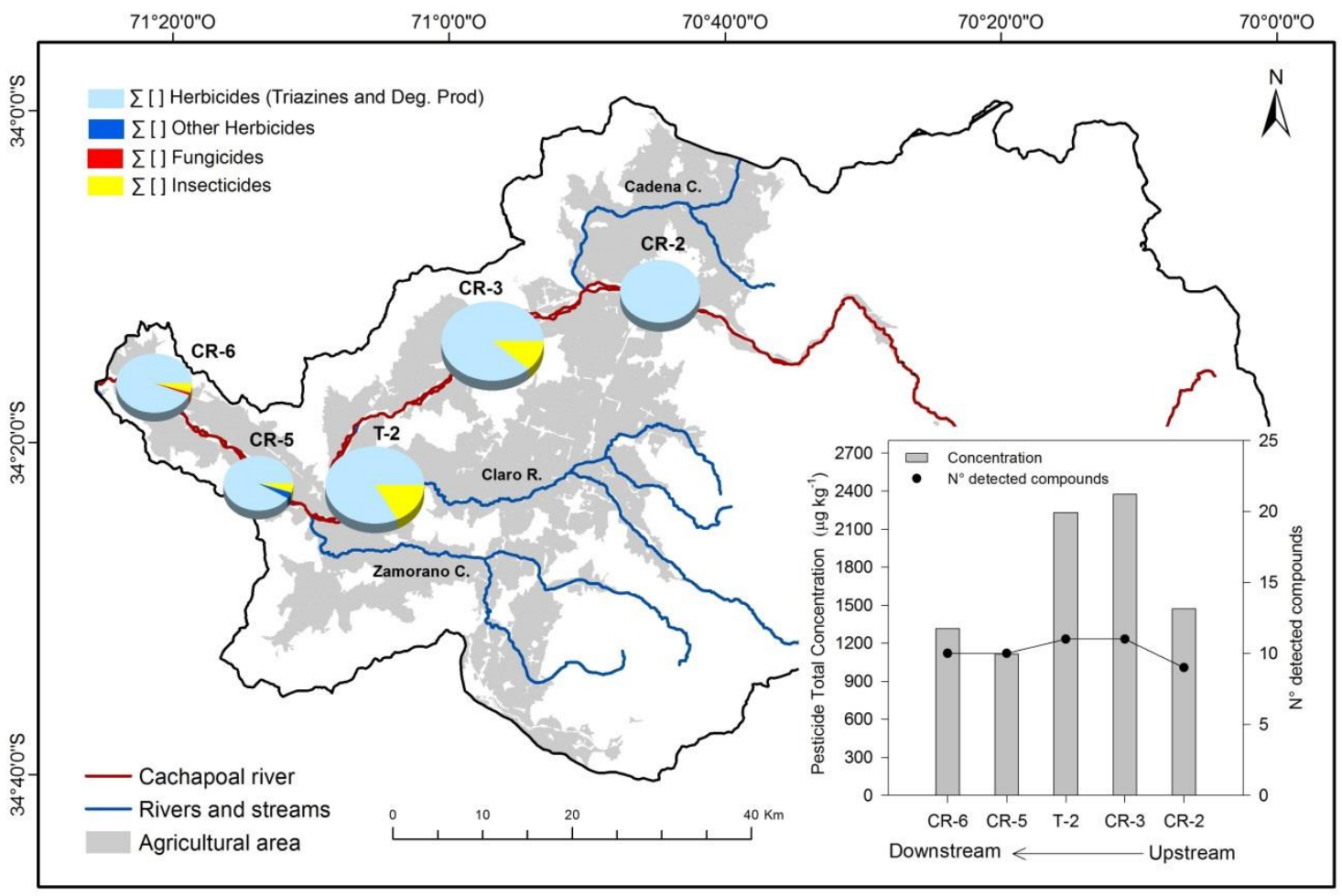

Figure 5. Total concentration of pesticides and degradation products $\left(\mu \mathrm{g} \mathrm{kg}^{-1}\right)$, number of detected compounds and spatial distribution of different pesticide groups (\%) in particulate phase of water samples collected along Cachapoal River and its tributaries. Data correspond to values determined in different sites in September, year 2015. 


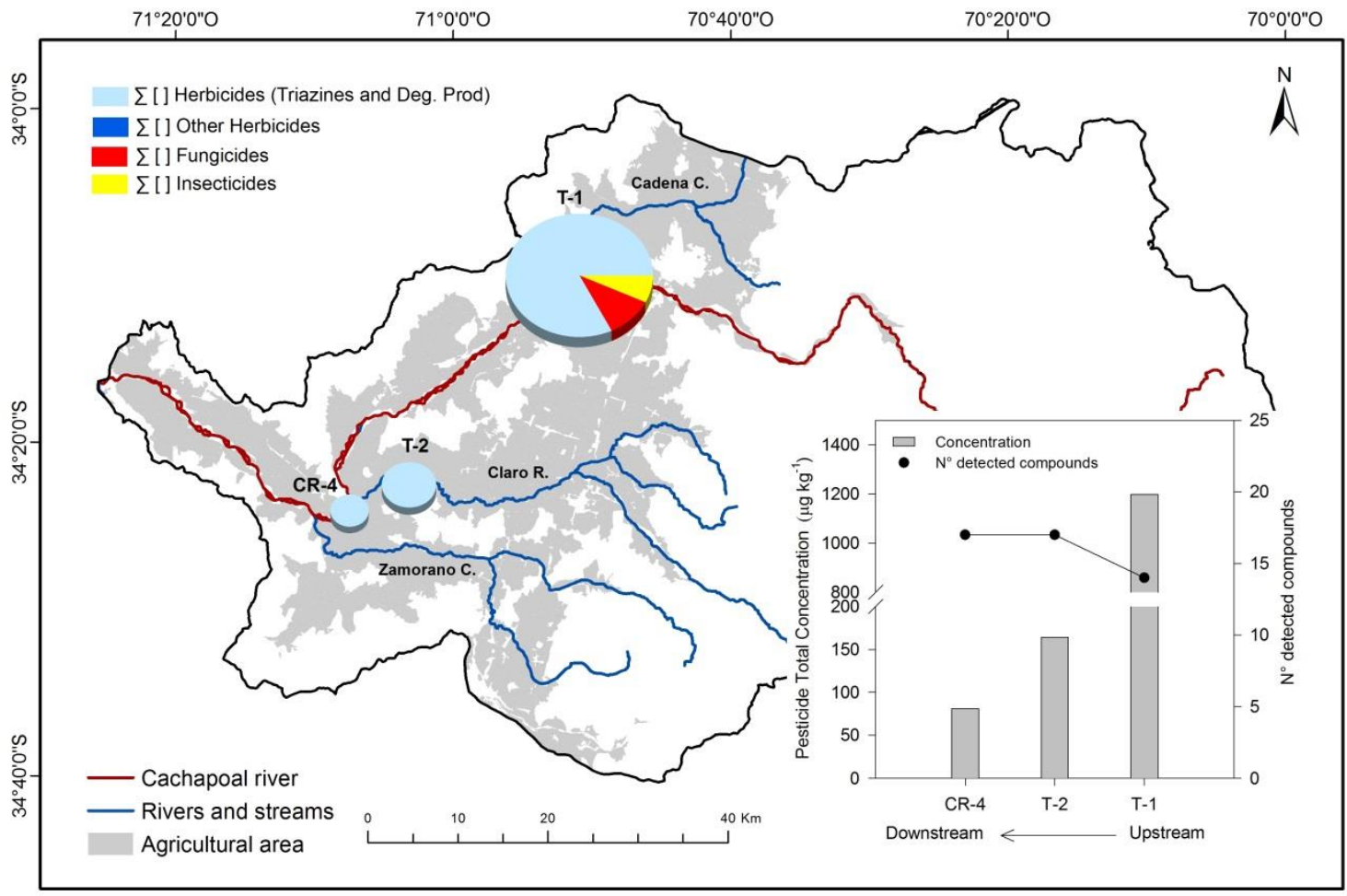

Figure 6. Total concentration of pesticides and degradation products $\left(\mu \mathrm{g} \mathrm{kg}^{-1}\right)$, number of detected compounds and spatial distribution of different pesticide groups (\%) in particulate phase of water samples collected along Cachapoal River and its tributaries. Data correspond to values determined in different sites in April after rainfall, year 2016. 
Table 1. Physicochemical properties of pesticides and their degradation products. Compounds with letters in brackets correspond to the degradation products of the parent compound with the same letter in the superscript.

\begin{tabular}{|c|c|c|c|c|c|c|}
\hline Pesticide & Chemical group & $\begin{array}{c}\mathrm{SW} \\
\left(\mathrm{mg} \mathrm{L}^{-1}\right)\end{array}$ & $\begin{array}{c}\text { log } \\
\text { Kow }\end{array}$ & $\begin{array}{c}\mathrm{Koc} \\
\left(\mathrm{ml} \mathrm{g}^{-1}\right)\end{array}$ & $\begin{array}{c}\mathrm{DT}_{50} \text { soil } \\
\text { (days)* }\end{array}$ & $\begin{array}{c}\mathrm{DT}_{50} \text { water } \\
\text { (days) } * *\end{array}$ \\
\hline \multicolumn{7}{|l|}{ Degradation product } \\
\hline DIHA (a) & Degr. Prod. & $1000000^{(1)}$ & $-3.12^{(1)}$ & - & - & - \\
\hline DEHA (b) & Degr. Prod. & $1000000^{(1)}$ & $-2.70^{(1)}$ & - & - & - \\
\hline DIA (c) & Degr. Prod. & $670^{(1)}$ & $1.15^{(1)}$ & $55.66^{(1)}$ & - & - \\
\hline DEA (d) & Degr. Prod. & $3200^{(1)}$ & $1.51^{(1)}$ & 110 & 45 & - \\
\hline $\operatorname{DET}(\mathrm{e})$ & Degr. Prod. & 327.1 & 2.3 & $122.8^{(1)}$ & 70.5 & Stable \\
\hline $\mathrm{HA}(\mathrm{f})$ & Degr. Prod. & 5.9 & 2.09 & - & 164 & - \\
\hline HT (g) & Degr. Prod. & 7.19 & $-1.29^{(1)}$ & $3542^{(1)}$ & 453 & - \\
\hline CGA $92370(\mathrm{~h})$ & Degr. Prod. & - & - & - & - & - \\
\hline Pyrimidinol (i) & Degr. Prod. & $25160^{(1)}$ & $0.55^{(1)}$ & $62.31^{(1)}$ & 126 & Stable \\
\hline Diazoxon (j) & Degr. Prod. & $245.1^{(1)}$ & $2.10^{(1)}$ & $174.7^{(1)}$ & - & - \\
\hline Chlorpyrifosoxon (1) & Degr. Prod. & $25.97^{(1)}$ & $2.89^{(1)}$ & $415.1^{(1)}$ & - & - \\
\hline \multicolumn{7}{|l|}{ Herbicides } \\
\hline Atrazine $^{(\mathrm{a}, \mathrm{b}, \mathrm{c}, \mathrm{d}, \mathrm{f})}$ & Triazine & 35 & 2.7 & 100 & 75 & 86 \\
\hline Terbuthylazine $e^{(\mathrm{a}, \mathrm{c}, \mathrm{e}, \mathrm{g})}$ & Triazine & 6.6 & 3.4 & $309^{(1)}$ & 75.1 & Stable \\
\hline Simazine & Triazine & 5.0 & 2.3 & 130 & 60 & 96 \\
\hline Propazine & Triazine & 8.6 & 3.95 & 154 & 131 & 83 \\
\hline Diuron & Phenylurea & 35.6 & 2.87 & 813 & 75.5 & Stable \\
\hline Fluometuron & Phenylamide & 111 & 2.28 & $154.3^{(1)}$ & 63.6 & Stable \\
\hline Acetochlor & Chloroacetamide & 282 & 4.14 & 156 & 14 & Stable \\
\hline \multicolumn{7}{|l|}{ Fungicides } \\
\hline Metalaxyl $^{(\mathrm{h})}$ & Acylalanine & 8400 & 1.75 & 162 & 36 & 106 \\
\hline Azoxystrobin & Strobilurin & 6.7 & 2.5 & 589 & 78 & Stable \\
\hline Kresoxim-methyl & Strobilurin & 2 & 3.4 & $625.3^{(1)}$ & 16 & 35 \\
\hline Cyproconazole & Triazole & 93 & 3.09 & $155.1^{(1)}$ & 142 & Stable \\
\hline Flutriafol & Triazole & 95 & 2.3 & $71.32^{(1)}$ & 1358 & Stable \\
\hline Myclobutanil & Triazole & 132 & 2.89 & $1038^{(1)}$ & 560 & Stable \\
\hline Tebuconazole & Triazole & 36 & 3.7 & $429.7^{(1)}$ & 63 & Stable \\
\hline Pyrimethanil & Anilinopyrimidine & 121 & 2.84 & $709.9^{(1)}$ & 55 & Stable \\
\hline Cyprodinil & Anilinopyrimidine & 13 & 4.0 & $3111^{(1)}$ & 37 & Stable \\
\hline \multicolumn{7}{|l|}{ Insecticides } \\
\hline Diazinon $^{(\mathrm{i}, \mathrm{j})}$ & Organophosphate & 60 & 3.69 & 609 & 9.1 & 138 \\
\hline Chlorpyrifos $^{(1)}$ & Organophosphate & 1.05 & 4.7 & 8151 & 50 & 25.5 \\
\hline Acephate $^{(\mathrm{l})}$ & Organophosphate & 790000 & -0.85 & 302 & 3 & 50 \\
\hline Azinphosmethyl & Organophosphate & 28 & 2.96 & 1112 & 10 & 50 \\
\hline Methidathion & Organophosphate & 240 & 2.57 & 400 & 10 & 27 \\
\hline Imidacloprid & Neonicotinoid & 610 & 0.57 & $33.64^{(1)}$ & 191 & Stable \\
\hline Methamidophos & Organophosphate & 200000 & -0.79 & 1.0 & 3.5 & 5 \\
\hline
\end{tabular}

Sw: Solubility in water at $20^{\circ} \mathrm{C}$; Kow: Octanol-water partitioning coefficient at $\mathrm{pH} 7$ and $20^{\circ} \mathrm{C}$; Koc: Soil sorption coefficient; *half life in soil under aerobic conditions; **half life by aqueous hydrolysis at $20^{\circ} \mathrm{C}$ and pH 7.0. Data taken from Lewis et al. (2016) and EpiSuite Program (version 4.1) ${ }^{(1)}$ and -: no data available. 
Table 2. Date and sampled sites in Cachapoal River and tributaries. Daily rainfall for each date is included at upper and lower area of Cachapoal River basin.

\begin{tabular}{|c|c|c|c|c|c|}
\hline Date & Season & Sampled sites & $\begin{array}{c}\text { Daily rainfall } \\
\text { at upper area } \\
(\mathrm{mm})^{*}\end{array}$ & $\begin{array}{c}\text { Daily rainfall at } \\
\text { lower area } \\
(\mathrm{mm})^{* *}\end{array}$ & $\begin{array}{c}\text { Amount of } \\
\text { collected } \\
\text { samples } \\
\end{array}$ \\
\hline September 8, 2015 & $\begin{array}{c}\text { Spring } \\
\text { (without rain) }\end{array}$ & $\begin{array}{l}\text { CR-1; CR-2; CR-3; } \\
\text { CR-5; CR-6; T-1; T-2 }\end{array}$ & 9.4 & 0.0 & 7 \\
\hline October 27, 2015 & $\begin{array}{c}\text { Spring } \\
\text { (without rain) }\end{array}$ & $\begin{array}{l}\text { CR-1; CR-2; CR-3; } \\
\text { CR-5; CR-6; T-1; T-2 }\end{array}$ & 0.0 & 0.0 & 7 \\
\hline April 13, 2016 & $\begin{array}{c}\text { Autumn } \\
\text { (without rain) }\end{array}$ & CR-4; T-1; T-2; T-3 & 10.4 & 1.8 & 4 \\
\hline April 14, 2016 & $\begin{array}{l}\text { Autumn } \\
\text { (with rain) }\end{array}$ & CR-4; T-1; T-2; T-3 & 101.7 & 16.8 & 4 \\
\hline July 13, 2016 & $\begin{array}{c}\text { Winter } \\
\text { (with rain) }\end{array}$ & $\mathrm{T}-1 ; \mathrm{T}-2 ; \mathrm{T}-3$ & 52.7 & 33.4 & 3 \\
\hline
\end{tabular}

*Data taken from weather station of General Directorate of Waters, Cachapoal River 5 km. water down in Junta Cortaderal. ** Weather station of General Directorate of Waters, Cachapoal River in Puente Arqueado (CA). http://snia.dga.cl/BNAConsultas/reportes (Accessed March, 12, 2018) 
Table 3. LC-MS quality control parameters for determination of pesticides and degradation products in dissolved and particulate phase in stream water.

\begin{tabular}{|c|c|c|c|c|c|c|c|c|}
\hline \multirow[b]{2}{*}{ Compound } & \multicolumn{4}{|c|}{ Dissolved phase } & \multicolumn{4}{|c|}{ Particulate phase } \\
\hline & $\begin{array}{c}\text { Recovery } \\
(\%)\end{array}$ & $\begin{array}{c}\mathrm{r}^{2} \\
\left(0.075-1.50 \mu \mathrm{g} \mathrm{L}^{-1}\right)\end{array}$ & $\begin{array}{c}\text { LOD } \\
\left(\mu \mathrm{g} \mathrm{L}^{-1}\right)\end{array}$ & $\begin{array}{c}\text { LOQ } \\
\left(\mu \mathrm{g} \mathrm{L}^{-1}\right)\end{array}$ & $\begin{array}{c}\text { Recovery } \\
(\%)\end{array}$ & $\begin{array}{c}\mathrm{r}^{2} \\
\left(0.1-1.0 \mu \mathrm{g} \mathrm{Kg}^{-1}\right)\end{array}$ & $\begin{array}{c}\mathrm{LOD} \\
\left(\mu \mathrm{g} \mathrm{Kg}^{-1}\right)\end{array}$ & $\begin{array}{c}\mathrm{LOQ} \\
\left(\mu \mathrm{g} \mathrm{Kg}^{-1}\right)\end{array}$ \\
\hline Methamidophos & 37 & 0.996 & 0.115 & 0.385 & 59 & 0.996 & 2.600 & 8.667 \\
\hline DIHA & 52 & 0.995 & 0.103 & 0.342 & 2 & 0.995 & 7.455 & 24.85 \\
\hline Acephate & 58 & 0.998 & 0.061 & 0.205 & 44 & 0.999 & 4.625 & 15.41 \\
\hline DEHA & 33 & 0.998 & 0.112 & 0.374 & 5 & 0.991 & 4.178 & 13.92 \\
\hline Pyrimidinol & 60 & 0.997 & 0.015 & 0.049 & 39 & 0.999 & 4.727 & 15.75 \\
\hline DIA & 70 & 0.999 & 0.014 & 0.048 & 50 & 0.998 & 2.052 & 6.839 \\
\hline Imidacloprid & 95 & 0.996 & 0.013 & 0.042 & 33 & 0.999 & 2.203 & 7.343 \\
\hline DEA & 78 & 0.998 & 0.011 & 0.037 & 78 & 0.996 & 1.131 & 3.771 \\
\hline HA & 102 & 0.998 & 0.022 & 0.073 & 8 & 0.999 & 3.272 & 10.91 \\
\hline CGA 92370 & 77 & 0.992 & 0.012 & 0.038 & 74 & 0.999 & 1.056 & 3.519 \\
\hline HT & 103 & 0.996 & 0.014 & 0.048 & 21 & 0.997 & 3.107 & 10.35 \\
\hline DET & 78 & 0.998 & 0.014 & 0.045 & 86 & 0.996 & 1.433 & 4.778 \\
\hline Flutriafol & 89 & 0.999 & 0.011 & 0.036 & 75 & 0.996 & 2.150 & 7.167 \\
\hline Atrazine & 81 & 0.996 & 0.014 & 0.045 & 84 & 0.997 & 0.920 & 3.068 \\
\hline Metalaxyl & 103 & 0.995 & 0.010 & 0.034 & 98 & 0.999 & 0.642 & 2.142 \\
\hline Fluometuron & 85 & 0.999 & 0.019 & 0.062 & 78 & 0.998 & 1.389 & 4.629 \\
\hline Diazoxon & 107 & 0.995 & 0.014 & 0.046 & 84 & 0.999 & 2.241 & 7.470 \\
\hline Cyproconazole & 73 & 0.998 & 0.012 & 0.042 & 54 & 0.998 & 2.588 & 8.628 \\
\hline Azoxystrobin & 81 & 0.999 & 0.003 & 0.009 & 93 & 0.999 & 0.914 & 3.047 \\
\hline Diuron & 72 & 0.995 & 0.010 & 0.034 & 85 & 0.995 & 2.506 & 8.354 \\
\hline Propazine & 95 & 0.996 & 0.005 & 0.016 & 81 & 0.993 & 0.456 & 1.520 \\
\hline Terbuthylazine & 87 & 0.997 & 0.001 & 0.005 & 116 & 0.999 & 0.649 & 2.163 \\
\hline Myclobutanil & 87 & 0.999 & 0.015 & 0.051 & 83 & 0.999 & 4.446 & 14.82 \\
\hline Methidathion & 63 & 0.999 & 0.020 & 0.068 & 77 & 0.999 & 3.291 & 10.97 \\
\hline Pyrimethanil & 57 & 0.996 & 0.001 & 0.004 & 67 & 0.999 & 4.290 & 14.30 \\
\hline Azinphosmethyl & 59 & 0.996 & 0.010 & 0.035 & 61 & 0.997 & 3.470 & 11.57 \\
\hline Acetochlor & 63 & 0.996 & 0.022 & 0.072 & 82 & 0.998 & 4.009 & 13.36 \\
\hline Chlorpyrifosoxon & 62 & 0.998 & 0.015 & 0.049 & 1 & 0.998 & 4.499 & 14.99 \\
\hline Kresoxim-methyl & 69 & 0.995 & 0.022 & 0.072 & 72 & 0.999 & 0.931 & 3.104 \\
\hline Tebuconazole & 76 & 0.998 & 0.022 & 0.067 & 62 & 0.999 & 2.112 & 7.039 \\
\hline Diazinon & 76 & 0.998 & 0.009 & 0.029 & 110 & 0.999 & 2.234 & 7.447 \\
\hline Cyprodinil & 80 & 0.999 & 0.020 & 0.067 & 49 & 0.999 & 2.493 & 8.309 \\
\hline Chlorpyrifos & 59 & 0.999 & 0.014 & 0.048 & 23 & 0.999 & 2.255 & 7.518 \\
\hline
\end{tabular}




\title{
Supporting Information
}

\section{Residues of Pesticides and Some Metabolites in Dissolved and Particulate Phase in Surface Stream Water of Cachapoal River Basin, Central Chile}

\author{
María José Climent ${ }^{1,2}$, Eliseo Herrero-Hernández ${ }^{3, *}$, María Jesús Sánchez-Martín ${ }^{3}$, María \\ Sonia Rodríguez-Cruz ${ }^{3}$, Pablo Pedreros ${ }^{1,2}$, Roberto Urrutia ${ }^{1,2}$ \\ ${ }^{1}$ Faculty of Environmental Sciences \& EULA Center, Universidad de Concepción, Barrio \\ Universitario $s / n, 4030000$ Concepción, Chile. \\ ${ }^{2}$ Center for Water Resources for Agriculture and Mining (CRHIAM), Universidad de \\ Concepción, Victoria 1295, 4030000 Concepción, Chile. \\ ${ }^{3}$ Institute of Natural Resources and Agrobiology of Salamanca, IRNASA-CSIC, c/ Cordel \\ de Merinas, 40-52, 37008 Salamanca, España.
}

\section{Corresponding Autor}

Eliseo Herrero-Hernández

e-mail address: elihh@usal.es

Telephone number: +34 923219606; Fax: +34 923219609

Permanent address: c/ Cordel de Merinas, 40-52, 37008 Salamanca, España. 
Table S1. Chromatographic conditions and mass detector optimization parameters (LC-MS) for analytical determination of pesticides and their degradation products in dissolved and particulate phase in surface water.

\begin{tabular}{|c|c|c|c|c|}
\hline Compound & $\mathrm{RT}(\min )$ & SIM window & $\mathrm{m} / \mathrm{z}$ & $\mathrm{V}$ cone $(\mathrm{V})$ \\
\hline Methamidophos & 7.09 & 1 & 142.0 & 15 \\
\hline DIHA & 7.14 & 1 & 156.1 & 30 \\
\hline Acephate & 7.30 & 1 & 184.1 & 15 \\
\hline DEHA & 7.80 & 1 & 170.1 & 30 \\
\hline Pyrimidinol & 9.18 & 2 & 153.0 & 25 \\
\hline DIA & 9.85 & 2 & 174.0 & 25 \\
\hline Imidacloprid & 10.15 & 2 & 256.2 & 15 \\
\hline DEA & 11.67 & 3 & 188.1 & 20 \\
\hline HA & 11.82 & 3 & 198.1 & 25 \\
\hline CGA 92370 & 12.10 & 3 & 194.2 & 20 \\
\hline HT & 14.00 & 3 & 212.2 & 25 \\
\hline DET & 14.24 & 3 & 202.2 & 20 \\
\hline Flutriafol & 15.20 & 3 & 302.2 & 20 \\
\hline Atrazine & 16.77 & 4 & 216.1 & 30 \\
\hline Metalaxyl & 16.96 & 4 & 280.2 & 25 \\
\hline Fluometuron & 17.65 & 4 & 233.2 & 25 \\
\hline Diazoxon & 17.94 & 4 & 289.0 & 20 \\
\hline Cyproconazole & 18.79 & 4 & 292.2 & 15 \\
\hline Azoxystrobin & 19.14 & 4 & 404.2 & 25 \\
\hline Diuron & 19.61 & 4 & 233.2 & 25 \\
\hline Propazine & 19.44 & 5 & 230.2 & 15 \\
\hline Terbuthylazine & 19.67 & 5 & 230.2 & 15 \\
\hline Myclobutanil & 20.31 & 5 & 289.1 & 25 \\
\hline Methidathion & 20.71 & 5 & 303.0 & 20 \\
\hline Pyrimethanil & 21.00 & 5 & 200.2 & 35 \\
\hline Azinphos methyl & 21.21 & 5 & 318.3 & 20 \\
\hline Acetochlor & 22.62 & 5 & 270.2 & 15 \\
\hline Chlorpyrifos oxon & 23.48 & 6 & 334.0 & 20 \\
\hline Kresoxim-methyl & 24.69 & 6 & 314.4 & 20 \\
\hline Tebuconazole & 25.38 & 6 & 308.2 & 25 \\
\hline Diazinon & 25.86 & 6 & 305.2 & 20 \\
\hline Cyprodinil & 25.92 & 6 & 226.2 & 35 \\
\hline Chlorpyrifos & 28.58 & 6 & 350.1 & 20 \\
\hline
\end{tabular}


Table S2. Chromatographic conditions and mass detector optimization parameters (GC-MS) for the determination of pesticides and some degradation products in dissolved phase in surface water.

\begin{tabular}{|c|c|c|c|c|}
\hline \multirow{2}{*}{ Compound } & \multirow{2}{*}{$\begin{array}{c}\mathrm{RT} \\
(\mathrm{min})\end{array}$} & \multirow{2}{*}{ SIM window } & \multicolumn{2}{|c|}{ Monitored ions (Abundance) } \\
\hline & & & Quantification ion & Identification ions $(\mathrm{m} / \mathrm{z})$ \\
\hline Fluometuron & 4.8 & 1 & 174 & $219(794) / 187(536)$ \\
\hline CGA 92370 & 7.5 & 1 & 148 & $120(572) / 91(322)$ \\
\hline DIA & 8.0 & 1 & 173 & $158(870) / 145(751)$ \\
\hline DEA & 8.2 & 1 & 172 & $187(349) / 174(309)$ \\
\hline DET & 8.6 & 1 & 186 & $188(319) / 83(287)$ \\
\hline Simazine & 9.9 & 2 & 201 & $44(798) / 186(565)$ \\
\hline Atrazine & 10.2 & 2 & 200 & $215(615) / 58(378)$ \\
\hline Diazoxon & 10.6 & 2 & 273 & $137(740) / 288(319)$ \\
\hline Terbuthylazine & 10.8 & 2 & 214 & $43(574) / 173(512)$ \\
\hline Diazinon & 11.2 & 2 & 137 & $152(659) / 179(569)$ \\
\hline Pyrimethanil & 11.4 & 2 & 198 & 199 \\
\hline Acetochloro & 13.9 & 3 & 59 & $146(839) / 162(696)$ \\
\hline Metalaxyl & 15.1 & 3 & 45 & $206(326) / 132(299)$ \\
\hline Chlorpyrifos & 17.7 & 3 & 197 & $199(974) / 314(865)$ \\
\hline Cyprodinil & 20.8 & 3 & 224 & $225(616) / 210(100)$ \\
\hline Kresoxim-methyl & 26.7 & 3 & 116 & $131(533) / 206(516)$ \\
\hline
\end{tabular}


Table S3. Average $\left(\mu \mathrm{g} \mathrm{L}^{-1}\right)$ concentration of pesticides and/or degradation products concentrations detected in dissolved phase of surface water samples (by triplicate) collected at 2015. Total concentration $\left(\sum[]\right)$ of pesticides and amount $\left(\mathrm{N}^{\circ}\right)$ of pesticides detected by sampling site.

\begin{tabular}{|c|c|c|c|c|c|c|c|c|c|c|c|c|c|c|}
\hline \multirow[t]{2}{*}{ Compound } & \multicolumn{7}{|c|}{$\begin{array}{l}\text { Spring (without rain), September } 2015 \\
\qquad(\mathrm{n}=7)\end{array}$} & \multicolumn{7}{|c|}{$\begin{array}{l}\text { Spring (without rain), October } 2015 \\
(\mathrm{n}=7)\end{array}$} \\
\hline & CR-1 & CR-2 & $\mathrm{T}-1$ & CR-3 & $\mathrm{T}-2$ & CR-5 & CR-6 & CR-1 & CR-2 & $\mathrm{T}-1$ & CR-3 & $\mathrm{T}-2$ & CR-5 & CR-6 \\
\hline Fluometuron & n.d & n.d & n.d & n.d & n.d & n.d & n.d & n.d & n.d & n.d & n.d & n.d & n.d & n.d \\
\hline Diuron & n.d & n.d & 0.363 & 0.056 & $<\mathrm{LOQ}$ & 0.073 & 0.103 & n.d & n.d & n.d & n.d & n.d & n.d & n.d \\
\hline Propazine & n.d & n.d & n.d & n.d & n.d & n.d & n.d & n.d & n.d & n.d & n.d & n.d & n.d & n.d \\
\hline Acetochloro & n.d & n.d & n.d & n.d & n.d & n.d & n.d & n.d & $<\mathrm{LOQ}$ & n.d & n.d & n.d & $<\mathrm{LOQ}$ & $<\mathrm{LOQ}$ \\
\hline Simazine & n.d & n.d & $<\mathrm{LOQ}$ & $<\mathrm{LOQ}$ & $<\mathrm{LOQ}$ & $<\mathrm{LOQ}$ & $<\mathrm{LOQ}$ & n.d & n.d & $<\mathrm{LOQ}$ & $<\mathrm{LOQ}$ & $<\mathrm{LOQ}$ & $<\mathrm{LOQ}$ & $<$ LOQ \\
\hline Terbuthylazine & n.d & n.d & $<\mathrm{LOQ}$ & $<\mathrm{LOQ}$ & $<\mathrm{LOQ}$ & $<\mathrm{LOQ}$ & 0.022 & n.d & n.d & n.d & n.d & n.d & n.d & $<\mathrm{LOQ}$ \\
\hline Atrazine & n.d & n.d & $<\mathrm{LOQ}$ & $<\mathrm{LOQ}$ & $<\mathrm{LOQ}$ & $<\mathrm{LOQ}$ & $<\mathrm{LOQ}$ & n.d & n.d & 0.055 & $<\mathrm{LOQ}$ & $<\mathrm{LOQ}$ & $<\mathrm{LOQ}$ & $<$ LOQ \\
\hline $\mathrm{HT}$ & n.d & n.d & n.d & n.d & n.d & n.d & n.d & n.d & n.d & n.d & n.d & n.d & n.d & n.d \\
\hline DIHA & n.d & 1.015 & 1.101 & 0.634 & 0.713 & 0.840 & 1.127 & n.d & 0.411 & n.d & 0.902 & 0.692 & 0.910 & 0.393 \\
\hline DEHA & n.d & n.d & n.d & n.d & n.d & n.d & n.d & n.d & n.d & n.d & n.d & n.d & n.d & n.d \\
\hline DIA & n.d & n.d & n.d & n.d & 0.049 & 0.053 & 0.064 & n.d & n.d & n.d & $<\mathrm{LOQ}$ & n.d & 0.051 & 0.05 \\
\hline DEA & n.d & n.d & n.d & n.d & 0.049 & $<\mathrm{LOQ}$ & 0.037 & n.d & n.d & n.d & n.d & $<\mathrm{LOQ}$ & 0.039 & $<\mathrm{LOQ}$ \\
\hline DET & n.d & n.d & $<\mathrm{LOQ}$ & $<\mathrm{LOQ}$ & $<\mathrm{LOQ}$ & $<\mathrm{LOQ}$ & $<\mathrm{LOQ}$ & n.d & n.d & $<\mathrm{LOQ}$ & $<\mathrm{LOQ}$ & $<\mathrm{LOQ}$ & $<\mathrm{LOQ}$ & $<$ LOQ \\
\hline HA & n.d & $<\mathrm{LOQ}$ & $<\mathrm{LOQ}$ & $<\mathrm{LOQ}$ & $<\mathrm{LOQ}$ & $<\mathrm{LOQ}$ & $<\mathrm{LOQ}$ & n.d & n.d & < LOQ & n.d & $<\mathrm{LOQ}$ & $<\mathrm{LOQ}$ & $<$ LOQ \\
\hline Flutriafol & n.d & n.d & n.d & n.d & 0.048 & n.d & 0.050 & n.d & n.d & n.d & n.d & n.d & n.d & n.d \\
\hline Pyrimethanil & n.d & n.d & 0.118 & $<\mathrm{LOQ}$ & 0.005 & $<\mathrm{LOQ}$ & 0.009 & n.d & n.d & 0.093 & $<\mathrm{LOQ}$ & $<\mathrm{LOQ}$ & $<\mathrm{LOQ}$ & $<\mathrm{LOQ}$ \\
\hline Myclobutanil & n.d & n.d & n.d & n.d & $<\mathrm{LOQ}$ & $<\mathrm{LOQ}$ & $<\mathrm{LOQ}$ & n.d & n.d & n.d & n.d & n.d & n.d & $<$ LOQ \\
\hline Cyprodinil & n.d & n.d & $<\mathrm{LOQ}$ & $<\mathrm{LOQ}$ & $<\mathrm{LOQ}$ & $<\mathrm{LOQ}$ & $<\mathrm{LOQ}$ & n.d & n.d & $<\mathrm{LOQ}$ & $<\mathrm{LOQ}$ & $<\mathrm{LOQ}$ & $<\mathrm{LOQ}$ & $<\mathrm{LOQ}$ \\
\hline Cyproconazole & n.d & n.d & n.d & n.d & n.d & n.d & n.d & n.d & n.d & n.d & n.d & n.d & n.d & n.d \\
\hline Tebuconazole & n.d & n.d & 0.229 & 0.069 & $<\mathrm{LOQ}$ & 0.083 & 0.145 & n.d & n.d & 0.100 & $<\mathrm{LOQ}$ & 0.113 & 0.101 & 0.092 \\
\hline Azoxystrobin & n.d & n.d & n.d & n.d & $<\mathrm{LOQ}$ & 0.01 & $<\mathrm{LOQ}$ & n.d & n.d & n.d & n.d & 0.037 & 0.015 & 0.012 \\
\hline Kresoxim-methyl & n.d & n.d & n.d & n.d & n.d & n.d & n.d & n.d & n.d & n.d & n.d & n.d & n.d & n.d \\
\hline Metalaxyl & n.d & n.d & n.d & n.d & $<\mathrm{LOQ}$ & n.d & $<\mathrm{LOQ}$ & n.d & n.d & n.d & n.d & $<\mathrm{LOQ}$ & $<\mathrm{LOQ}$ & $<$ LOQ \\
\hline CGA 92370 & n.d & n.d & n.d & n.d & n.d & n.d & n.d & n.d & n.d & n.d & n.d & n.d & n.d & n.d \\
\hline Methamidophos & n.d & $<\mathrm{LOQ}$ & $<\mathrm{LOQ}$ & $<\mathrm{LOQ}$ & $<\mathrm{LOQ}$ & $<\mathrm{LOQ}$ & $<\mathrm{LOQ}$ & n.d & n.d & n.d & $<\mathrm{LOQ}$ & $<\mathrm{LOQ}$ & $<\mathrm{LOQ}$ & $<\mathrm{LOQ}$ \\
\hline Acephate & n.d & n.d & 4.887 & 2.338 & 0.293 & 0.473 & 0.387 & n.d & n.d & 4.446 & 1.561 & n.d & 0.627 & 0.358 \\
\hline Imidacloprid & n.d & n.d & n.d & n.d & n.d & n.d & 0.067 & n.d & n.d & 0.085 & 0.054 & 0.054 & 0.064 & 0.070 \\
\hline Methidathion & n.d & n.d & n.d & n.d & n.d & $<\mathrm{LOQ}$ & $<\mathrm{LOQ}$ & n.d & n.d & n.d & n.d & n.d & n.d & n.d \\
\hline Azinphos-methyl & n.d & n.d & n.d & n.d & n.d & n.d & n.d & n.d & n.d & n.d & n.d & n.d & n.d & n.d \\
\hline Diazinon & n.d & n.d & n.d & n.d & $<\mathrm{LOQ}$ & $<\mathrm{LOQ}$ & $<\mathrm{LOQ}$ & n.d & n.d & n.d & n.d & n.d & 0.318 & 0.177 \\
\hline Pyrimidinol & n.d & n.d & n.d & n.d & n.d & n.d & n.d & n.d & n.d & 0.099 & $<\mathrm{LOQ}$ & $<\mathrm{LOQ}$ & $<\mathrm{LOQ}$ & $<$ LOQ \\
\hline Diazoxon & n.d & n.d & n.d & n.d & n.d & n.d & n.d & n.d & n.d & n.d & $<\mathrm{LOQ}$ & n.d & n.d & n.d \\
\hline Chlorpyrifos & n.d & n.d & n.d & n.d & n.d & 0.08 & $<\mathrm{LOQ}$ & n.d & n.d & 0.090 & n.d & $<\mathrm{LOQ}$ & $<\mathrm{LOQ}$ & 0.056 \\
\hline Chlorpyrifos-oxon & n.d & n.d & 0.054 & n.d & n.d & n.d & n.d & n.d & n.d & n.d & n.d & n.d & n.d & n.d \\
\hline
\end{tabular}




\begin{tabular}{|c|c|c|c|c|c|c|c|c|c|c|c|c|c|c|}
\hline $\begin{array}{l}\sum[] \text { Herbicides } \\
\text { (Triazines and Deg. Prod) }\end{array}$ & n.d & 1.015 & 1.101 & 0.634 & 0.811 & 0.893 & 1.250 & n.d & 0.411 & 0.055 & 0.902 & 0.692 & 1.00 & 0.443 \\
\hline$\sum[$ ] Other Herbicides & n.d & n.d & 0.363 & 0.056 & $<\mathrm{LOQ}$ & 0.073 & 0.103 & n.d & $<\mathrm{LOQ}$ & n.d & n.d & n.d & $<\mathrm{LOQ}$ & $<\mathrm{LOQ}$ \\
\hline$\sum[$ ] Fungicides & n.d & n.d & 0.346 & 0.069 & 0.053 & 0.093 & 0.203 & n.d & n.d & 0.192 & $<\mathrm{LOQ}$ & 0.150 & 0.116 & 0.104 \\
\hline$\sum[$ ] Insecticides & n.d & $<\mathrm{LOQ}$ & 4.941 & 2.338 & 0.293 & 0.553 & 0.454 & n.d & n.d & 4.720 & 1.615 & 0.054 & 1.008 & 0.661 \\
\hline$\sum[$ ] Total & n.d & 1.015 & 6.751 & 3.097 & 1.156 & 1.611 & 2.009 & n.d & 0.411 & 4.967 & 2.517 & 0.896 & 2.123 & 1.208 \\
\hline $\mathrm{N}^{\circ}$ Detected compounds & 0 & 3 & 13 & 12 & 19 & 19 & 22 & 0 & 2 & 11 & 13 & 15 & 19 & 21 \\
\hline
\end{tabular}

CR: Cachapoal River; T-1: Cadena creek.; T-2: Claro river.; n.d: not detected.; < LOQ: Concentrations detected above LOD but lower than LOQ. 
Table S4. Average $\left(\mu \mathrm{g} \mathrm{L}^{-1}\right)$ of pesticides and/or degradation products concentrations detected in dissolved phase of surface water samples (by triplicate) collected at 2016. Total concentration $\left(\sum[]^{2}\right.$ and amount $\left(\mathrm{N}^{\circ}\right)$ of pesticides detected by sampling site.

\begin{tabular}{|c|c|c|c|c|c|c|c|c|c|c|c|}
\hline \multirow[t]{2}{*}{ Compound } & \multicolumn{4}{|c|}{$\begin{array}{c}\text { Autumn (without rain) } \\
(\mathrm{n}=4)\end{array}$} & \multicolumn{4}{|c|}{$\begin{array}{c}\text { Autumn (with rain) } \\
(\mathrm{n}=4)\end{array}$} & \multicolumn{3}{|c|}{$\begin{array}{l}\text { Winter (with rain) } \\
(\mathrm{n}=3)\end{array}$} \\
\hline & $\mathrm{T}-1$ & $\mathrm{~T}-2$ & $\mathrm{~T}-3$ & CR-4 & $\mathrm{T}-1$ & $\mathrm{~T}-2$ & T-3 & CR-4 & T-1 & $\mathrm{T}-2$ & $\mathrm{~T}-3$ \\
\hline Fluometuron & n.d & n.d & n.d & n.d & n.d & n.d & n.d & n.d & n.d & n.d & n.d \\
\hline Diuron & 0.076 & n.d & n.d & n.d & n.d & n.d & n.d & n.d & 3.952 & 1.440 & 2.299 \\
\hline Propazine & n.d & n.d & n.d & n.d & n.d & n.d & n.d & n.d & n.d & n.d & n.d \\
\hline Acetochloro & n.d & n.d & n.d & n.d & $<\mathrm{LOQ}$ & n.d & n.d & n.d & n.d & n.d & n.d \\
\hline Simazine & $<\mathrm{LOQ}$ & n.d & $<\mathrm{LOQ}$ & $<\mathrm{LOQ}$ & $<\mathrm{LOQ}$ & $<\mathrm{LOQ}$ & n.d & $<\mathrm{LOQ}$ & 1.227 & $<\mathrm{LOQ}$ & n.d \\
\hline Terbuthylazine & $<$ LOQ & $<\mathrm{LOQ}$ & $<\mathrm{LOQ}$ & $<\mathrm{LOQ}$ & $<$ LOQ & $<$ LOQ & $<$ LOQ & $<\mathrm{LOQ}$ & 0.116 & $<\mathrm{LOQ}$ & 0.869 \\
\hline Atrazine & $<\mathrm{LOQ}$ & $<\mathrm{LOQ}$ & $<\mathrm{LOQ}$ & $<\mathrm{LOQ}$ & $<\mathrm{LOQ}$ & $<\mathrm{LOQ}$ & $<\mathrm{LOQ}$ & $<\mathrm{LOQ}$ & 0.149 & $<\mathrm{LOQ}$ & $<\mathrm{LOQ}$ \\
\hline HT & n.d & n.d & n.d & n.d & $<\mathrm{LOQ}$ & $<\mathrm{LOQ}$ & n.d & n.d & n.d & n.d & n.d \\
\hline DIHA & n.d & $<\mathrm{LOQ}$ & 0.374 & 0.455 & n.d & n.d & n.d & 0.380 & n.d & 0.803 & n.d \\
\hline DEHA & $<\mathrm{LOQ}$ & 0.485 & $<\mathrm{LOQ}$ & $<\mathrm{LOQ}$ & $<\mathrm{LOQ}$ & $<\mathrm{LOQ}$ & $<\mathrm{LOQ}$ & n.d & n.d & n.d & n.d \\
\hline DIA & n.d & n.d & n.d & n.d & 0.053 & n.d & n.d & n.d & 0.064 & 0.052 & 0.154 \\
\hline DEA & $<\mathrm{LOQ}$ & $<\mathrm{LOQ}$ & 0.042 & $<\mathrm{LOQ}$ & n.d & n.d & 0.048 & n.d & n.d & 0.039 & 0.046 \\
\hline DET & n.d & $<\mathrm{LOQ}$ & $<\mathrm{LOQ}$ & $<\mathrm{LOQ}$ & n.d & n.d & n.d & n.d & n.d & n.d & $<\mathrm{LOQ}$ \\
\hline HA & $<\mathrm{LOQ}$ & $<\mathrm{LOQ}$ & $<\mathrm{LOQ}$ & $<\mathrm{LOQ}$ & 0.084 & $<\mathrm{LOQ}$ & $<$ LOQ & $<\mathrm{LOQ}$ & $<\mathrm{LOQ}$ & $<\mathrm{LOQ}$ & $<\mathrm{LOQ}$ \\
\hline Flutriafol & n.d & n.d & n.d & n.d & 0.051 & n.d & n.d & n.d & 0.125 & n.d & n.d \\
\hline Pyrimethanil & 0.176 & 0.017 & 0.108 & 0.084 & 0.184 & $<$ LOQ & 2.898 & 0.047 & 0.086 & $<\mathrm{LOQ}$ & 0.231 \\
\hline Myclobutanil & n.d & n.d & $<\mathrm{LOQ}$ & n.d & 0.063 & $<$ LOQ & $<$ LOQ & $<$ LOQ & 0.053 & $<\mathrm{LOQ}$ & 0.067 \\
\hline Cyprodinil & $<\mathrm{LOQ}$ & $<\mathrm{LOQ}$ & $<\mathrm{LOQ}$ & $<\mathrm{LOQ}$ & $<\mathrm{LOQ}$ & $<\mathrm{LOQ}$ & $<\mathrm{LOQ}$ & $<\mathrm{LOQ}$ & 0.204 & $<\mathrm{LOQ}$ & $<\mathrm{LOQ}$ \\
\hline Cyproconazole & n.d & n.d & n.d & n.d & n.d & n.d & n.d & n.d & n.d & n.d & n.d \\
\hline Tebuconazole & 0.736 & $<\mathrm{LOQ}$ & $<\mathrm{LOQ}$ & 0.127 & 0.964 & 0.153 & 0.145 & $<\mathrm{LOQ}$ & 0.460 & $<\mathrm{LOQ}$ & 0.340 \\
\hline Azoxystrobin & n.d & 0.013 & n.d & n.d & 0,019 & 0.015 & 0.013 & n.d & n.d & $<\mathrm{LOQ}$ & 0.011 \\
\hline Kresoxim-methyl & n.d & n.d & n.d & n.d & 0.133 & n.d & n.d & n.d & n.d & n.d & n.d \\
\hline Metalaxyl & n.d & n.d & n.d & n.d & $<$ LOQ & $<\mathrm{LOQ}$ & 0.061 & 0.047 & n.d & $<$ LOQ & 0.049 \\
\hline CGA 92370 & n.d & n.d & n.d & n.d & n.d & n.d & n.d & n.d & n.d & n.d & n.d \\
\hline Methamidophos & n.d & $<\mathrm{LOQ}$ & $<\mathrm{LOQ}$ & $<\mathrm{LOQ}$ & n.d & $<\mathrm{LOQ}$ & $<$ LOQ & $<\mathrm{LOQ}$ & $<$ LOQ & $<\mathrm{LOQ}$ & $<\mathrm{LOQ}$ \\
\hline Acephate & 1.889 & n.d & n.d & 1.286 & 0.578 & n.d & $<\mathrm{LOQ}$ & 0.235 & 0.782 & n.d & 0.245 \\
\hline Imidacloprid & 0.054 & 0.046 & 0.050 & 0.046 & 0.171 & 0.120 & 0.125 & 0.131 & 0.070 & 0.059 & 0.111 \\
\hline Methidathion & n.d & n.d & n.d & n.d & n.d & 0,251 & 0,204 & 0,146 & n.d & n.d & n.d \\
\hline Azinphos-methyl & n.d & n.d & n.d & n.d & n.d & n.d & n.d & n.d & n.d & n.d & n.d \\
\hline Diazinon & 0.060 & $<\mathrm{LOQ}$ & $<\mathrm{LOQ}$ & 0.033 & 0.141 & 0.106 & 0.159 & 0.154 & 0.195 & 0.050 & 0.129 \\
\hline Pyrimidinol & n.d & n.d & n.d & n.d & n.d & n.d & n.d & n.d & n.d & n.d & n.d \\
\hline Diazoxon & n.d & n.d & n.d & n.d & n.d & n.d & n.d & n.d & n.d & n.d & n.d \\
\hline Chlorpyrifos & n.d & n.d & n.d & n.d & n.d & n.d & n.d & n.d & n.d & 0.069 & n.d \\
\hline Chlorpyrifos-oxon & n.d & $<\mathrm{LOQ}$ & n.d & $<$ LOQ & $<$ LOQ & n.d & $<$ LOQ & $<$ LOQ & 0.049 & $<$ LOQ & 0.055 \\
\hline $\begin{array}{l}\sum[] \text { Herbicides } \\
\text { (Triazines and Deg. Prod) }\end{array}$ & $<$ LOQ & 0.485 & 0.416 & 0.455 & 0.137 & $<$ LOQ & 0.048 & 0.380 & 1.556 & 0.894 & 1.068 \\
\hline$\sum[$ ] Other Herbicides & 0.076 & n.d & n.d & n.d & $<$ LOQ & n.d & n.d & n.d & 3.952 & 1.4395 & 2.299 \\
\hline$\sum$ [ ] Fungicides & 0.911 & 0.029 & 0.108 & 0.211 & 1.413 & 0.168 & 3.116 & 0.094 & 0.927 & $<\mathrm{LOQ}$ & 0.697 \\
\hline $\bar{\Sigma}[$ ] Insecticides & 2.002 & 0.046 & 0.050 & 1.364 & 0.889 & 0.477 & 0.488 & 0.664 & 1.095 & 0.177 & 0.539 \\
\hline$\sum[]$ Total & 2.989 & 0.560 & 0.573 & 2.030 & 2.439 & 0.644 & 3.651 & 1.138 & 7.530 & 2.510 & 4.603 \\
\hline $\mathrm{N}^{\circ}$ Detected compounds & 13 & 15 & 15 & 16 & 20 & 16 & 17 & 16 & 16 & 19 & 18 \\
\hline
\end{tabular}

T-1: Cadena creek.; T-2: Claro river.; T-3: Zamoranos creek.; CR: Cachapoal River.; n.d: not detected; < LOQ: concentrations detected above LOD but lower than LOQ. 
Table S5. Average $\left(\mu \mathrm{g} \mathrm{Kg}^{-1}\right)$ of pesticides and/or degradation products concentrations detected in particulate phase of surface water samples (by triplicate) collected in September 2015 and Autumn (with rain) 2016. Total concentration $\left(\sum[]\right)$ and amount $\left(\mathrm{N}^{\circ}\right)$ of pesticides detected by sampling site.

\begin{tabular}{|c|c|c|c|c|c|c|c|c|}
\hline \multirow{2}{*}{ Compound } & \multicolumn{5}{|c|}{ Spring (without rain), September 2015} & \multicolumn{3}{|c|}{ Autumn (with rain), 2016} \\
\hline & CR-2 & CR-3 & $\mathrm{T}-2$ & CR-5 & CR-6 & $\mathrm{T}-1$ & $\mathrm{~T}-2$ & CR-4 \\
\hline Fluometuron & n.d & n.d & n.d & n.d & n.d & n.d & n.d & n.d \\
\hline Diuron & n.d & n.d & n.d & $<$ LOQ & n.d & $<\mathrm{LOQ}$ & $<\mathrm{LOQ}$ & $<\mathrm{LOQ}$ \\
\hline Propazine & n.d & n.d & n.d & n.d & n.d & n.d & n.d & n.d \\
\hline Acetochloro & $<$ LOQ & $<\mathrm{LOQ}$ & 18.66 & 35.48 & n.d & $<\mathrm{LOQ}$ & $<\mathrm{LOQ}$ & $<\mathrm{LOQ}$ \\
\hline Terbuthylazine & n.d & n.d & n.d & n.d & n.d & n.d & n.d & n.d \\
\hline Atrazine & n.d & n.d & n.d & n.d & n.d & n.d & $<\mathrm{LOQ}$ & $<\mathrm{LOQ}$ \\
\hline HT & 933.8 & 89.94 & n.d & n.d & n.d & n.d & n.d & n.d \\
\hline DIHA & 314.2 & 1123 & 652.5 & n.d & 347.7 & 207.8 & n.d & n.d \\
\hline DEHA & n.d & 425.1 & n.d & n.d & n.d & 35.69 & 52.17 & 22.63 \\
\hline DIA & n.d & n.d & n.d & n.d & n.d & n.d & n.d & n.d \\
\hline DEA & n.d & n.d & n.d & 5.67 & $<\mathrm{LOQ}$ & n.d & n.d & n.d \\
\hline DET & n.d & n.d & n.d & n.d & n.d & 279.5 & $<\mathrm{LOQ}$ & $<\mathrm{LOQ}$ \\
\hline HA & 223.0 & 473.6 & 1195 & 1014 & 894.9 & 473.8 & 111.6 & 58.50 \\
\hline Flutriafol & n.d & n.d & n.d & n.d & n.d & n.d & n.d & n.d \\
\hline Pyrimethanil & $<\mathrm{LOQ}$ & n.d & $<\mathrm{LOQ}$ & $<\mathrm{LOQ}$ & $<\mathrm{LOQ}$ & $<\mathrm{LOQ}$ & $<\mathrm{LOQ}$ & $<\mathrm{LOQ}$ \\
\hline Myclobutanil & n.d & n.d & n.d & n.d & n.d & n.d & n.d & $<\mathrm{LOQ}$ \\
\hline Cyprodinil & n.d & n.d & $<\mathrm{LOQ}$ & $<\mathrm{LOQ}$ & $<\mathrm{LOQ}$ & 20.18 & $<\mathrm{LOQ}$ & $<\mathrm{LOQ}$ \\
\hline Cyproconazole & n.d & n.d & n.d & n.d & n.d & n.d & n.d & n.d \\
\hline Tebuconazole & n.d & n.d & 7.75 & 9.54 & 12.09 & 105.3 & $<\mathrm{LOQ}$ & $<\mathrm{LOQ}$ \\
\hline Azoxystrobin & n.d & n.d & n.d & n.d & n.d & n.d & $<\mathrm{LOQ}$ & $<\mathrm{LOQ}$ \\
\hline Kresoxim-methyl & n.d & n.d & n.d & n.d & n.d & n.d & n.d & n.d \\
\hline Metalaxyl & $<\mathrm{LOQ}$ & 2.63 & $<\mathrm{LOQ}$ & n.d & 2.18 & $<\mathrm{LOQ}$ & $<\mathrm{LOQ}$ & $<\mathrm{LOQ}$ \\
\hline CGA 92370 & n.d & n.d & n.d & n.d & n.d & n.d & n.d & n.d \\
\hline Methamidophos & n.d & 38.40 & n.d & n.d & n.d & 18.31 & n.d & n.d \\
\hline Acephate & n.d & n.d & n.d & n.d & n.d & n.d & n.d & n.d \\
\hline Imidacloprid & $<\mathrm{LOQ}$ & 20.93 & 10.57 & 12.51 & 15.21 & 17.36 & $<\mathrm{LOQ}$ & $<\mathrm{LOQ}$ \\
\hline Methidathion & n.d & n.d & n.d & n.d & n.d & n.d & $<\mathrm{LOQ}$ & n.d \\
\hline Azinphos-methyl & n.d & n.d & n.d & n.d & n.d & n.d & n.d & n.d \\
\hline Diazinon & $<\mathrm{LOQ}$ & $<\mathrm{LOQ}$ & 14.34 & 16.25 & 21.49 & 10.82 & $<\mathrm{LOQ}$ & $<\mathrm{LOQ}$ \\
\hline Pyrimidinol & $<\mathrm{LOQ}$ & 39.69 & 19.56 & 22.69 & 21.89 & 29.94 & $<\mathrm{LOQ}$ & $<\mathrm{LOQ}$ \\
\hline Diazoxon & n.d & n.d & n.d & n.d & n.d & n.d & n.d & n.d \\
\hline Chlorpyrifos & n.d & 160.78 & n.d & n.d & n.d & n.d & $<\mathrm{LOQ}$ & $<\mathrm{LOQ}$ \\
\hline Chlorpyrifos-oxon & n.d & n.d & 313.3 & n.d & n.d & n.d & $<\mathrm{LOQ}$ & $<\mathrm{LOQ}$ \\
\hline $\begin{array}{l}\sum[] \text { Herbicides } \\
\text { (Triazines and Deg. Prod) }\end{array}$ & 1471 & 2112 & 1848 & 1021 & 1243 & 996.9 & 163.8 & 81.1 \\
\hline$\sum[$ ] Other Herbicides & $<\mathrm{LOQ}$ & $<\mathrm{LOQ}$ & 18,7 & 35.5 & n.d & $<\mathrm{LOQ}$ & $<\mathrm{LOQ}$ & $<\mathrm{LOQ}$ \\
\hline$\sum[$ ] Fungicides & $<\mathrm{LOQ}$ & 2.6 & 7.8 & 9.5 & 14,3 & 125.5 & $<\mathrm{LOQ}$ & $<\mathrm{LOQ}$ \\
\hline$\sum[$ ] Insecticides & $<\mathrm{LOQ}$ & 259.8 & 357.8 & 51.4 & 58.6 & 76.44 & $<\mathrm{LOQ}$ & $<\mathrm{LOQ}$ \\
\hline$\sum[$ ] Total & 1471 & 2375 & 2232 & 1117 & 1315 & 1199 & 163.8 & 81.1 \\
\hline $\mathrm{N}^{\circ}$ Detected compounds & 9 & 11 & 11 & 10 & 10 & 14 & 17 & 17 \\
\hline
\end{tabular}

T-1: Cadena creek.; T-2: Claro river.; T-3: Zamoranos creek.; CR: Cachapoal River.; n.d: not detected; < LOQ: concentrations detected above LOD but lower than LOQ. 


\section{Highlights}

1. First study in Chile that reveals the occurrence of pesticides in the particulate phase of aqueous samples.

2. Acephate, DIHA, diuron and pyrimethanil, highest concentrations in dissolved phase.

3. Triazine-derived degradation products, highest concentrations in particulate phase.

4. Increase in number of detected pesticides in dissolved phase from upper to lower area of Cachapoal River basin.

5. It is necessary evaluate the possible pollution of groundwater because can it be used for domestic purposes. 


\section{Graphical Abstract}

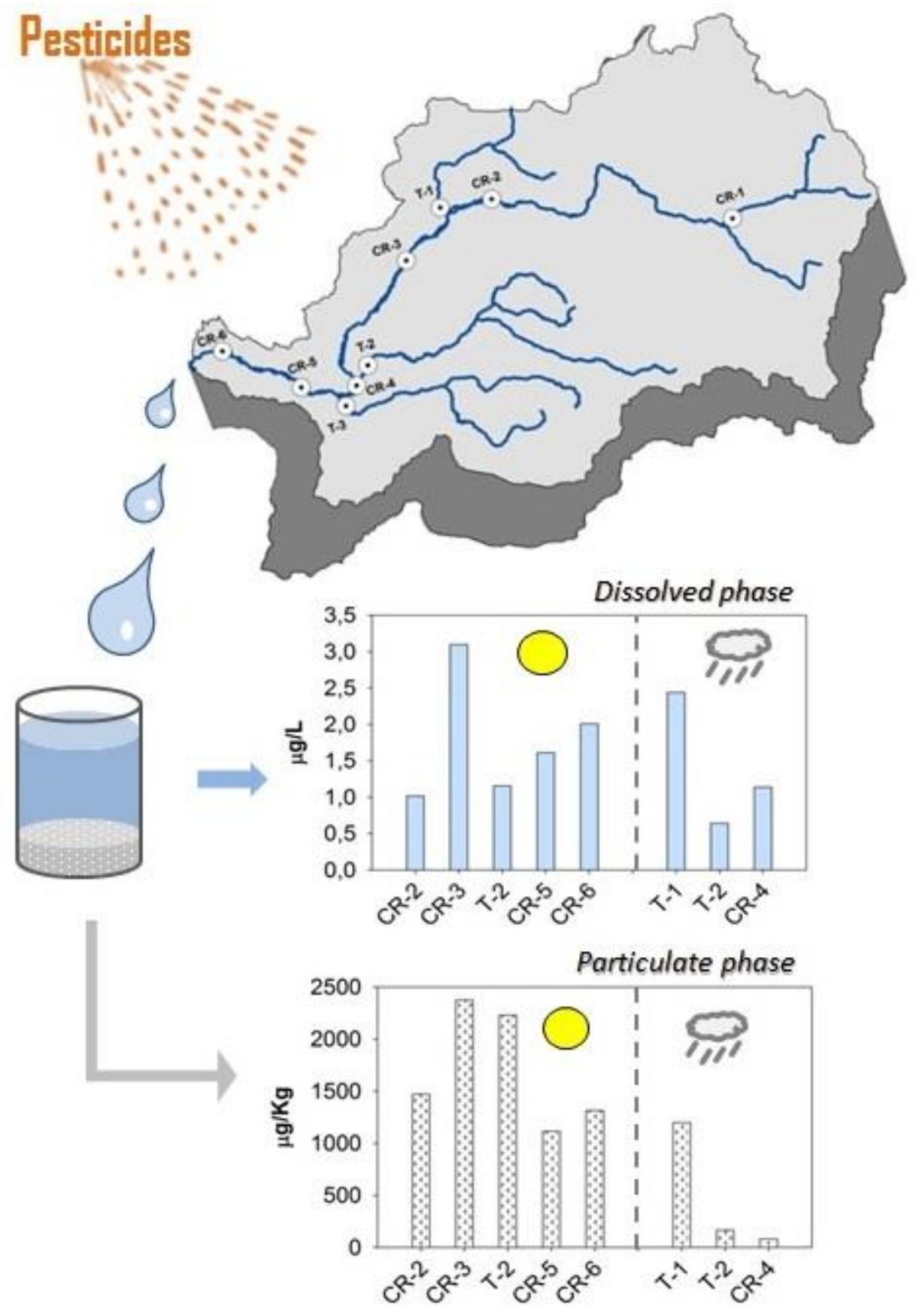

